\title{
Taşkın Tespitinin Farklı Yöntemlerle Değerlendirilmesi: Ayamama Deresi Örneği
}

\author{
Orkan Özcan ${ }^{1, *}$ \\ 1'istanbul Teknik Üniversitesi, Avrasya Yer Bilimleri Enstitüsü, 34469, Maslak İstanbul.

\section{Özet}

Gelişmekte olan birçok ülkede hızlı kentleşme, afet riskleri ve etkilenebilirlikler büyük sorun teşkil etmektedir. Kontrolsüz gelişmeler, yoğun yerleșim yerleri ve yetersiz altyapı ile ilgili mevcut riskleri ortaya çıkarmaktadır. Tehlikeli alanların haritalanmasındaki gelişmeler, toplum etkilenebilirliklerinin değerlendirilmesi ve yıkıcı güçlere karşı dayanıklı tasarımların yapılması, kayıpların azaltılması için yeni firsatlar yaratmışıı. Bu çalışmanın amacı, taşkın analizinde en çok kullanılan; i) Çok Kriterli Karar Verme, ii) Hidrolik Modelleme, iii) Bilgi Difüzyon Teorisi ve iv) Ĕ̆ri Numarası (SCS-CN) yöntemlerinin değerlendirmesi ve karşılaştırmasıdır. Elde edilen sonuçlar ışığında; oluşturulan etkilenebilirlik haritasına göre toplamda 1995 binanın etkilenebilir alanlar içerisinde bulunduğu ve bunların 420 'sinin çok yüksek etkilenebilir alanlarda olduğu belirlenmiștir. Ayamama Deresi için yapılan modelleme sonucuna göre $185 \mathrm{~m}^{3} / \mathrm{s}$ 'lik kararlı akımın yaklaşık olarak 73 ha'lık bir alanı etkileyeceği sonucuna varlmış ve etkilenecek alanlar CBS ortamında belirlenmiștir. Yapılan obje-tabanlı en yakın komșuluk sinıflandırma sonucu temel alındiğında olası tașkında etkilenebilir alanda; toplamda 1859 binanın etkileneceği belirlenmiștir. Havzaya ait eğri numaraları SCS-CN yöntemi ile belirlenerek Bilgi Difüzyon yönteminde kullanılmıştır. Bilgi Difüzyonu analiz sonuçlarına göre; Ayamama Deresi $180 \mathrm{~m}^{3} / \mathrm{s}$ 'lik akıma ulaştı̆̆ında taşkın olma olasılığının yaklaşık olarak\% 97.2 olacă̆ı ve taşkın sularının yaklaşık 50 ha gibi bir alanda etkili olacağı belirlenmiştir.

\section{Anahtar Sözcükler}

Taşkın Analizi, Analitik Hiyerarși Süreci, Hidrolojik Modelleme, Difüzyon Teorisi, Eğri Numarası

\section{Evaluation of flood determination with various methods: Case study of Ayamama Creek}

\begin{abstract}
In many developing countries, rapid urbanization, disaster risks and affectability pose a great problem. Uncontrolled developments will bring out the inherent risks related with high-density environments and inadequate infrastructure. Advances in mapping hazardous areas have created new opportunities for assessing population vulnerabilities, doing designs to withstand against destructive forces and reducing losses. The aim of this study is to evaluate and compare the most used methods including i) Multi Criteria Decision Analysis, ii) Hydraulic Modeling, iii) Information Diffusion Theory and iv) SCS-CN (Soil Conservation Service Curve Number) in flood analysis. In the light of the results; 1995 buildings were found to be in vulnerable zones in total and 420 of them were found to be in a very high vulnerable zones according to the prepared affectability map. Hydrologic modeling results based on the defined discharge rate showed that 73 hectares of the urbanized area will be affected in the event of $185 \mathrm{~m}^{3} / \mathrm{s}$ of steady flow in Ayamama Creek and these areas were determined in GIS. Based upon the nearest neighbour object-based classification, total of 1859 buildings were defined to be affected by a potential flood. Curve numbers of the catchment were determined by using SCS-CN method and used in Information Diffusion method. According to the results of this method, when the Ayamama Creek reaches $180 \mathrm{~m}^{3} / \mathrm{s}$ of flow rate, the probability of flood occurrence is estimated to be \%97.2 and it was determined that the flood waters will be effective in about 50 hectares of the area.
\end{abstract}

\section{Keywords}

Flood Analysis, Analytic Hierarchy Process, Hydrologic Modeling, Diffusion Theory, Curve Number

\section{Giriş}

Doğal afet olarak nitelendirilen doğa olayları, genelde doğanın iç dengelerini yeniden düzenlemesine yönelik döngünün doğal sonuçları olup, insan topluluklarının bu döngüden zarar görmesi durumunda doğal afet olarak adlandırılmaktadırlar (Kilıçer vd. 2000). Ülkemizde sel ve taşkın, depremlerden sonra en büyük can ve mal kaybına neden olan doğal afetlerdir. Taşkınlar birçok bölge ve ülkede ekonomik ve sosyal hayatı etkileyen önemli doğal afetlerden biridir (CEOS 2003). Ülkemizde olduğu kadar tüm dünyada da önemli ölçüde can ve mal kaybına sebep olan taşkınlar, başta yaşanılan çevre olmak üzere, insanların sosyal ve ekonomik hayatlarını etkileyen en önemli doğal afetlerden birisidir. 
Günümüzde rastlanılan en yaygın taşkın oluşma sebebi; kuvvetli yağmur firtınalarında drenaj sistemlerindeki yetersizlik sonucu, ana nehir kanallarının tamamen dolu olması ile meydana gelen yüzeysel akış nedeniyle oluşan taşmalardır (Onuşluel ve Harmancığlu 2002). Taşkın afetlerini yalnızca meteorolojik oluşumlara bağlı olarak ifade etmek mümkün değildir. Özellikle Türkiye gibi ekonomik gelişme faaliyetinin yoğun bir biçimde devam ettiği ülkelerde, sanayileşme ve sektör çeşitliliğinin beraberinde getirdiği kentleşme aktivitesi, akarsu havzalarının muhtelif kesimlerindeki insan faaliyetinin çeşitliliğini ve yoğunluğunu da büyük ölçüde arttırmaktadır. Bu durum ise havza bütünündeki hidrolojik dengeyi bozmakta ve sonuçta büyük miktarda can ve mal kaybına yol açan taşkın afetleri yaşanmaktadır. Akarsu havzaları içinde büyüyen yerleşimler, açılan yeni yollar ve kurulan yeni tesisler ile arazi yapısı değişmekte, elverişsiz tarım yöntemleri ile topraklar daha yoğun bir şekilde kullanılmakta, ormanlar ve meralar tahrip edilmekte, tüm bu koşullarda taşkın afetleri giderek daha büyük ve sık olarak görülmektedir (Özcan 2007). Taşkınların ülkemizde yarattığı zararın en büyük nedeni, dere yataklarına verilen imar izni sonucu bu bölgede kurulan yerleşimin, dere yatağını kapatmasıdır. Bu durumda derenin, şiddetli yağış sonucunda, debisinin artmasıyla daralan yatağından taşması ve denize ulaşabilmesi için önüne çıkan yerleşimi sular altında bırakması kaçınılmazdır (Ozcan vd. 2008). İnsanoğlunun çevreyi, çıkarları doğrultusunda, tabiatın dengesini bozacak şekilde değiştirmesi yaşanacak felaketlerin ana kaynağını oluşturmaktadır (Saral 2010).

Dünya genelinde, afetlerden korunma stratejisi kapsamında afete dönüşmeden önlemlerin alınmasına olanak sağlayacak afetlere karşı risk yönetimi çalışmalarına geçilmektedir. Yine de bu yaklaşımdaki başarı, gelişmiş koruma ve uyarı sistemleri ile daha iyi afet acil durum planlaması vb. afet yönetim çalışmalarının bir arada yürütülmesine bağlıdır. Temel yaklaşımdaki bu değişim küresel iklim değişikliklerine bağlı olarak artan taşkınların ve diğer afetlerin tahminindeki belirsizliklere yol açmaktadır. Küresel iklim değişimi, arazi kullanımındaki değişimler gibi birçok faktör taşkın riskinin gelecekte nasıl olacağını ve bu risklerin ne kadar iyi yönetilebileceğini etkileyecektir (Kadığlu 2008). Bazı çalışmalarda, toplam yağış kestirimleri ile HadGEM2 (Hadley Global Environment Model 2) iklim modeli ve RCP4.5 (Regional Climate Model) salım senaryosu kullanarak benzeştirmeler yapılmış; Türkiye'de 2070-2100 yılları arasında 1970-2000 dönemi klimatolojisine göre yağış değişiminin kış mevsimi için ülkenin güneyinde $2 \mathrm{~mm} /$ gün kadar azalmasının, kuzeydoğusunda ise $1.6 \mathrm{~mm} /$ gün artmasının beklendiği ve Türkiye'nin genel olarak artan hava sıcaklıkları ve azalan yağış tutarları nedeniyle, iklim değişikliğinden çok fazla etkileneceğini belirtilmiştir (Öztürk vd. 2014; Türkeş 2016).

Sistematik bir süreç olan risk yönetimi; riskin tanımlanması, risk analizi ve risk miktarının belirlenmesinden oluşur. Olası bir taşkında can ve mal kaybını en aza indirmek ve taşkının olumsuz etkilerinin azaltılması için yapılması gereken çalışmalar taşkın alanlarındaki risk yönetimi ile gerçekleştirilebilmektedir. Risk yönetimi çalışmalarında; tehlike ve riskler belirlenmekte, risk senaryoları hazırlanmakta, korunma ve zarar azaltma önlemleri seçilmekte, sonuçlar güncel haritalar ve grafiklerle ortaya konmakta, kullanılabilecek kaynak ve imkânlar belirlenmekte, afetten korunma ve afet müdahalesi için en uygun seçenek ve öncelikler hakkında kararlar elenip uygulamaya geçilmektedir. Oluşacak taşkınların belirlenmesi, risk analizlerinin yapılması, afet öncesi ve sonrası planlamaların yapılabilmesinde sahip olunan bilgi büyük önem taşımaktadır. Bilginin üretilmesi ve organize edilmesi, uzun süreç alan çalışmalar gerektirmektedir. Bu nedenle; taşkın risk analizi oldukça karmaşık ve birçok meslek grubunu ilgilendiren bir konudur.

Uzaktan algılama teknikleri ve Coğrafi Bilgi Sistemleri (CBS) uygulamaları, kentleşme ve nehir akımları arasındaki ilişkinin belirlenmesinde yararlı araçlardır. Uydu görüntüleri, geniş alanlarda ve sürekli algılama yapma özellikleriyle birçok doğal felakete karşı önceden planlama yapılmasında, risk bölgelerinin belirlenmesinde ve sonuçların izlenmesinde vazgeçilmez bir kaynaktır. Uzaktan algılama, risk analizi yapılabilecek sistemlere birçok alanda veri kaynağ sağlamaktadır. Kurulacak sistemin ölçeğine ve gerekli verilerin özelliklerine bağlı olarak seçilecek uydu verisi ve uygun işlem adımları ile güncel ve yüksek doğrulukla veri/bilgi üretmek mümkündür. Uzaktan algılama verilerinden elde edilen sonuçların ve diğer veri gruplarının bir arada değerlendirilmesi, sorguların üretilmesi ve karar mekanizmalarına sonuç veri üretilmesinde CBS birçok olanak sunmaktadır (Özcan ve Musaoğlu 2009). Ayrıca; uzaktan algılama ve CBS'nin bütünleşik ve verimli kullanımı afet öncesi risk analizlerinin yapılmasında ve afet sonrası hasar tespit çalışmaları gibi önemli ve stratejik konularda büyük ölçüde fayda sağlamaktadır. Kentleşmenin nehir akımları üzerindeki etkisi belirlendiğinde, gelecekteki eğilimi tahmin etmek mümkün olacaktır.

Küçük drenaj alanına sahip havzalarda oluşan taşkınların çevreye verdikleri zarar bilgileri genellikle en fazla 30 yıllık oldukları için, bir yıllık bir periyodun üzerindeki risk göstergeleri ile uğraşırken, geçmiş verilerin eksikliği sorunu ile yüzleşmemiz gerekmektedir. Bu durum daha çok, olasılık hesabı yapan geleneksel risk analiz yöntemlerinin, örnekleme sayılarının genellikle 30'un üzerinde olmasından kaynaklanmaktadır. Eğer yetersiz veri ile çalışılırsa, elde edilen analitik sonuçlar, aşırı derecede hatalı olacaktır (Lihua ve Gaoyuan 2008). Bu nedenle taşkın risk analizlerinde kullanılan veriler yetersiz olmakta ve büyük problemler yaratmaktadır (Suzanne 2004). Bu tarz problemlerin analizinde kullanılabilecek bir yöntem olan Bilgi Difüzyon yönteminde (Huang 1997), elde bulunan örneklemeler bulanık bilgi olarak kabul edilmektedir. İdeal bulanık bilgiler bu yöntem kullanılarak, risk analizi yaparken güvenli bir sonuç elde etmek için işlenebilmektedir (Mossberger ve Hale 2002).

Türkiye, topoğrafik yapısının yüksek ve engebeli oluşu, jeolojik yapı ve toprakların erozyona karşı hassasiyeti, yarı kurak iklim şartlarının karakteristik özelliklerine sahip olması, şiddetli sağanak yağışlar sebebiyle, erozyon ve sel felaketine oldukça hassas bir yapıda bulunmaktadır (URL-1 2016). Yaz aylarında tropikal hava kütlelerinin, kış aylarında ise kuzeyden gelen polar hava kütlelerinin etkisi altında bulunmakla birlikte bu hava kütlelerinin kapladığı alan, etki 
süreleri ve frekansları Türkiye'de yağış ve sıcaklık koşullarının değişmesinde önemli rol oynamaktadır (Kömüşçü vd. 2011). Ülkemizde birçok farklı bölgesel alt iklim ve yağış rejimi tipleri bulunmasına karşın egemen iklim tipi, yazı kurak ve sıcak/çok sıcak subtropikal Akdeniz iklimi olmakla birlikte, yağış dağılımı $250 \mathrm{~mm}$ ile $2250 \mathrm{~mm}$ arasında değişiklik göstermekte olup bu yağış miktarı ilkbahar, yaz, sonbahar ve kış mevsimlerinde sırasıyla $177.1 \mathrm{~mm}, 62.3 \mathrm{~mm}, 154.4 \mathrm{~mm}$ ve 242.7 mm olarak gerçekleşmektedir (Türkeş 1998; Usta 2016). Bununla birlikte yaklaşık \%65'inde kurak ve yarı kurak iklim şartları hüküm sürmektedir. Türkiye yağışlarındaki uzun süreli eğilimler ve değişimlerin incelendiği çalışmalarda, genel olarak kıș ve ilkbahar yağıș toplamlarında Türkiye'nin Akdeniz yağış rejiminin egemen olduğu Marmara, Ege, Akdeniz ve Güneydoğu Anadolu bölgeleri ile İç ve Doğu Anadolu bölgelerinin iç ve güney bölümlerinde belirgin bir azalma eğiliminin olduğu belirtilmiştir (Türkeş 2012; Türkeş 2016). Türkiye'nin genel olarak batı ve güney bölgelerinde etkili olan yarı kurak subtropikal Akdeniz ikliminin en belirgin özelliği, hem mevsimselliğin hem de yıldan yıla ve daha uzun dönemli değişkenliğin çok yüksek olmasıdır (Türkeş 2010). Bu özellik, sık oluşan uzun dönemli kuraklıklarla ve kısa dönemli şiddetli yağışlarla açıklanmaktadır (Tatlı ve Türkeş 2011).

İstanbul İli, Marmara Denizi Havzası ile Karadeniz Havzası gibi iki büyük havza üzerinde bulunmakla birlikte tek bir akarsu havzasından oluşmayıp, çok sayıda küçük akarsu havzasının birleşmesinden meydana gelmiştir. Bölgede iklim, batıdan doğuya doğru yarı nemli iklimden nemli iklime geçişlidir (URL-2 2016). Orta Akdeniz ve Balkanlardan gelen cephe sistemlerinin etkisi ile özellikle sonbahar aylarında sık sık şiddetli yağışlara maruz kalmakla birlikte yukarı atmosferdeki güçlü hava hareketi ile alçak basınç sistemleri ekstrem yağışların oluşmasında önemli bir rol oynamaktadır (Lolis ve Türkeş 2016). Çalışma bölgesi olan İstanbul'da frontal faaliyetlerin arttığı kış mevsiminin yağışlı dönemi oluşturduğu Marmara yağış rejimi tipindedir. Bu yağış rejiminde en yüksek yağış miktarları Kasım, Aralık ve Ocak aylarında gerçekleşmekle birlikte özellikle Eylül ve Nisan aylarında düşen yağış miktarı yıllık ortalamanın yaklaşık \%10’unu meydana getirmektedir (Temuçin 1990).

Marmara Bölgesini 7 Eylül 2009 tarihinden itibaren 4 gün boyunca etkileyen yağışlı sistem Türkiye’yi özellikle kuzeybatı bölgelerinden itibaren etkilemeye başlamıştır. Burada görülen atmosferik koşullar benzer birçok diğer sel olaylarında görülen sinoptik desene oldukça benzemektedir. Bu tür sel olaylarına ait genel sinoptik deseninde, yüksek seviye haritalarında soğuk hava ve alçak basınç oluğu (trof) uzantısı ile sıcak hava ve sırt arasında kalan alanlarda şiddetli hava olaylarının meydana geldiği gözlemlenmiştir (Pontrelli vd. 1999). Yağışların devamlılığı sağlayan en önemli etkenlerden biri de atmosferin üst seviyelerindeki yüksek nispi (bağıl) nemdir. Yapılan bir çalışmada, 9 Eylül 2009 tarihli nispi nem haritasına göre İstanbul'un kuzeyinde atmosferdeki nispi nemin \%100'lere yakın gerçekleştiği ve bunun da yerdeki sıcak hava ve üst atmosferdeki nispi nemin dikey hareketin devamlılığını sağlayarak yağış etkinliğini artırdığı belirtilmiştir. Ortalama yıllık yağışı yaklaşık $852 \mathrm{~mm}$ olan bölgeye, bu tarihler arasında ortalama 74 mm yağış düşmüştür. 4 günlük zaman içerisinde düşen bu yağış uzun yıllar Eylül ayı ortalaması olan yaklaşık 36 mm değerinin 2 katını da geçmiştir (Kömüşçü vd. 2011).

İstanbul sadece günümüzde ya da yakın geçmişte değil 557 yıllık tarihi boyunca sellere maruz kalmış bir metropoldür. Osmanlı arşivlerinden edinilen bilgilerde, 450 sene önce, İstanbul dönemin en büyük sel felaketine maruz kalmış ve susuzluk çekmiştir. İçme suyu kaynakları zarar görmüş ve pek çok köprü yıkılmıştır. Bu durumun oluşmasında rol oynayan derelerin başında Ayamama ve çevresindeki dereler gelmektedir (URL-3 2010). İstanbul'da 09.09.2009'da meydana gelen taşkında, 6679 ha'lık drenaj alanına sahip 21 km uzunluğundaki Ayamama Deresi taşmış ve o günkü akım değeri yaklaşık olarak $185 \mathrm{~m}^{3} / \mathrm{s}$ ölçülmüştür (Özcan vd. 2011). 31 kişinin yaşamını yitirdiği ve yaklaşık zararın 150 milyon Euro $(€)$ olduğu bildirilen sel felaketinde, Ayamama Deresi son 500 yılın üzerinde yağış almış, İstanbul, can ve mal güvenliğini tehlikeye düşüren sonuçlarla karşılaşmıştır (Demir 2010). Ayamama Deresi'nde yaşanan afet, taşkın düzlüğünde 100-150 m genişliğindeki bir alanda, suyun 6-7 m yükselmesi ile can ve mal kaybına yol açmıştır. İstanbul İkitelli-Ayamama Havzası'nda yapılan etütlerde, bölge 7-8 Eylül tarihlerinde önemli miktarda yağış almış, 9 Eylül günü havzaya çok şiddetli bir yağış dalgası gelmiş, toprağın doygun olması nedeniyle yağış büyük oranda yüzeysel akışa geçerek taşkına neden olmuştur.

1982 tarihli hava fotoğraflarına göre hemen hemen hiç yapı bulunmayan Ayamama havzasının \%68'inin yapılaşmış olduğu, geri kalan \%32'sinin ise askeri bölge olması nedeni ile yapılaşmaya konu edilemediği görülmüştür. Yüksek yapılaşma oranı yağış-akış oranını yükseltmiştir. Ayamama Deresi Havzası, yukarı kısımda TEM otoyolu ile bölünmüş olup, burada oluşan taşkın ilk aşamada otoyol dolgusunun yukarısında toplanmış, buradaki menfez büyük su kütlelerinin Ayamama Deresi'nin taşkın yatağına ulaşma hızını azaltımıştır. TEM otoyolunun aşağısında ise Basın Ekspres Yolu olarak adlandırılan yol, Ayamama Deresi'nin taşkın yatağı üzerinde bulunması nedeniyle mevcut kanal yukarıdan gelen büyük su kütlesini drene edememiş ve yolun iki tarafında eski taşkın yatağına kurulmuş binalar ve yerleşimler su altında kalmıştır (Hızal vd. 2009).

Ayamama Deresi, 1slah edilmekle birlikte çevreye verdiği korku ve zarar hala devam etmektedir. Günümüzde Ayamama Deresi'nin Ataköy'de kalan bölümünün üzeri, kapatılarak kullanılmaktadır. Ayrıca İkitelli Organize Sanayi Bölgesi de Ayamama Deresi Havzası'nda kurulmuştur (Einfalt ve Keskin 2010). Yoğun kentleşmenin bulunduğu bölgede, dere yatağı üzerinde tamamen veya kısmen işgalci yapılar bulunmakta ve bu işgalci yapılar kısmen duvar veya yapı şeklinde olmaktadır. Hava fotoğrafları ve yerinde yapılan tespitlere göre derenin iki yakası boyunca tespit edilen yapı sayısı 108 adet olarak belirlenmiştir. Yapılaşmanın \%61'i TEM ile E-5 Karayolu arasında, \%39'u ise TEM'in kuzeyinde yer almaktadır (URL-4 2010). 
Bugünün dünyasında bilgi teknolojileri kullanılarak taşkın analizleri yapabilen sistemler oluşturulabilmekte ve bu afetler için önceden bir değerlendirme yapılabilmektedir (Özcan 2007). Taşkınları anlamak ve etkilerini ortaya koyabilmek için farklı modeller geliştirilmiştir. Bu modellerin, taşkın analizinde kullanımına bağlı olarak, kendi içerisinde avantaj ve dezavantajları bulunmaktadır. Bir modelin sahip olduğu sınırlamaları başka bir model giderirken, o modelin kullanımına bağlı sıkıntıları bir diğeri çözebilmektedir. Çalışmada, yüksek yapılaşmanın olduğu Ayamama Deresi’nde 09.09.2009 tarihinde yaşanan taşkın afeti sonrasında belirlenen gerçek hasarlar ile yöntemlerin uygulanması ile elde edilen sonuçların hem gerçek veri ile hem de birbirleri arasında karşılaștırılması amaçlanmıştır. Bu nedenle çalıșma kapsamında; Ayamama Deresi'nin taşkın analizinde, literatürde en çok kullanılan yöntemlerden i) Çok Kriterli Karar Verme Yöntemleri (MCDA), ii) Hidrolik Modelleme Yöntemi, iii) SCS-CN (Soil Conservation Service Curve Number) Yöntemi ve iv) Bilgi Difüzyon Teorisi üzerinde durulmuştur. Uygulanan yöntemler ile taşkın analizi için hem ihtiyaç duyulan verilerin temin edilemediği durumlarda yöntemler arası veri paylaşımının sağlanabileceği hem de bu yöntemlerin birbirleri arasındaki avantajları ve dezavantajları tartışılmıştır.

\section{Taşkın Duyarlılığının Belirlenmesi İçin Gereken Veriler}

Sel ve taşkınlar, havza yamaçlarından akarsu yataklarına ulaşan yüzeysel akışın hızla artmasından ve buna bağlı olarak akarsu yatağında akan su seviyesinin kısa sürede yükselerek yatak dışına taşmasından kaynaklanmaktadır (Görcelioğlu 2003). Bir havzada yüzeysel akışı ve buna bağlı olarak akarsu akımını etkileyen faktörler, iklim, fizyografik faktörler ile toprak tipi olarak üç ana grupta değerlendirilebilir (Tablo 1).

Meteorolojik gözlemler kapsamında yağış, sıcaklık, buharlaşma, nem, rüzgâr vb. ölçümler yapılır. Sel ve taşkınların belirlenmesinde yağış-akış ilişkisi hesabında genel olarak uzun yıllar toplam alansal yağış verileri kullanılmaktadır (Ulugür 1972; Özdemir 1978; Özer 2008). Toprağın su depolama kapasitesini aşarak yüzeysel akış meydana getirmeye yeterli olacak bir yağış ile yağış şiddetindeki artış, nehirlerdeki akım miktarında da hızlı bir artışa neden olacaktır. Havza büyüklüğü, akarsudaki toplam akım hacmini ve hidrografın şeklini etkilemekte, büyük yağış havzalarında sel ve taşkına neden olan akımlar küçük havzalardakine göre daha uzun süreli olmaktadır (Görcelioğlu 2003). Bir havzaya düşen yağış miktarı şiddet ve süre olarak arttıkça sel ve taşkın tehlikesi de artacaktır. Yükseklik, yağış kayıplarını etkilemesi bakımından önem taşımaktadır. Yükseklik verilerinin elde edilmesinin zahmetli bir işlem olması nedeniyle klasik hidrolojik yöntemlerde yüzeysel akış kestiriminde çoğu zaman yükseklik bilgileri kullanılmamaktadır. Ancak, CBS ortamında Sayısal Yükseklik Modeli (SYM) ile akış haritalarının kombinasyonu, akış oranının belirlenmesi ve taşkın duyarlılığının belirlenmesinde etkin olarak kullanılabilmektedir (Nyarko 2002). Yükseklik, biriken yağış miktarını etkilemesi bakımından büyük önem taşımaktadır. Eğim; yüzeysel akış, toprak nemi ve taban suyu tarafından akarsu akımına yapılan katkılar bakımından önemli bir faktördür. Eğim, biriken yağış miktarını etkilemekte ve özellikle düşük eğimlerde taşkın süresi daha uzun olmaktadır (Özdemir 1978). Bakı, güneşten alınan ısı enerjisi miktarına ve dolayısıyla terleme ve buharlaşma ile su kaybına etki etmektedir (Görcelioğlu 2003).

Bir su toplama havzası için drenaj ağı; ana suyolunun, su aldığı bütün yan dallarının meydana getirdiği akarsu şebekesidir (Özer 2008). Bir havzadaki drenaj durumu veya drenaj kapasitesi, o havzadaki doğal drenaj kanallarını oluşturan ana mecra ve ona bağlı bulunan yan kolların veya derelerin havzaya düşen yağış sularını boşaltabilme yeteneği veya kapasitesidir. Genel bir ifade ile bir havzanın drenaj yoğunluğu ne kadar yüksek ise, o havzadaki drenaj ağının yağıŞ sularını çevreye zarar vermeden akıtma yeteneğinin de o ölçüde yüksek olduğu söylenebilir (Görcelioğlu 2003). Drenaj yoğunluğu, birim alana düşen akarsu uzunluğu olarak tanımlanmaktadır. Bu yoğunluk, havzadaki sulu ve kuru derelerin uzunlukları toplamının havza alanına oranıyla elde edilmektedir.

Tablo 1: Akarsu akımını etkileyen faktörler

\begin{tabular}{lll}
\hline İklim Değişken ve Faktörleri & Fizyografik Değişken ve Faktörleri & Toprak Tipi ve Faktörleri \\
\hline Yağış & Havza özellikleri & Arazi kullanımı/örtüsü \\
Yağış tipi & Havza büyüklüğü & Toprak tipi \\
Yağış süresi & Yükseklik & Toprak tekstürü \\
Yağış dağılışı & Eğim & Toprak derinliği \\
Yağışın hareket yönü & Bakı & \\
Yağ1ş öncesi toprak nemi & Drenaj yoğunluğu & \\
Toprak yüzeyinden buharlaşma & Akarsu yatağ1 özellikleri & \\
Bitki yüzeylerinden buharlaşma & Yatak genişliği ve derinliği & \\
Bitki yüzeylerinden terleme & Enkesit formu ve alanı & \\
& Yatak eğimi ve eğim kırıklıkları & \\
& Kivrımlılık & \\
\hline
\end{tabular}


İnsanoğlunun faaliyetleri hidrolojik çevrimi etkilemektedir. Doğal bitki örtüsünün değişime uğraması, tutma, terleme ve sızma kayıplarını etkileyebilmekte ve bunun sonucunda da yüzeysel akış değişmektedir. Şehirleşmenin sızma kayıplarını azaltması da yüzeysel akış üzerinde etkili olmaktadır. Bu durum da düşen yağışın hızla akışa geçmesine ve etkili taşkınların oluşmasına neden olmaktadır (Bayazıt 2011). Toprak tipi sızmanın en önemli faktörü olmasından dolayı etkisini taşkının devamı boyunca göstermektedir. Toprağın tekstürü ise gözenek hacmi ve dağılışı, toprak derinliği, şişme ve büzülme özellikleri, sslanma yeteneği gibi nitelikleri su tutma ve yüzeysel akış üzerinde etkili olmakta ve bu nedenle de akarsu akımlarında önemli bir rol oynamaktadır (Özer 1990).

Taşkın duyarlılığının belirlenmesi için akarsu akımını etkileyen faktörlerden havzanın arazi kullanımı/örtüsü ile akarsu yatağı özellikleri doğrudan ve dolaylı olarak insan etkisine açıktır. Bir havzadaki arazi kullanım şekli, akarsu akımını doğrudan etkileyen bir faktördür. Arazi kullanımının insan eliyle kolayca değişikliğe uğratılabilen tek faktör olması, sel ve taşkın kontrolü bakımından önemini daha da arttırmaktadır.

$\mathrm{Bu}$ verilerin sağlıklı bir şekilde elde edilmesi, taşkın duyarlılığının yüksek doğrulukla belirlenmesi ve yapılacak risk çalışmalarında temel altlık veri olarak kullanılması bakımından önem arz etmektedir.

\section{Yöntemler}

\section{1. Çok Kriterli Karar Verme Yöntemi}

Çok Kriterli Karar Verme (Multi-Criteria Decision Analysis - MCDA) Yöntemi, sonlu sayıda seçeneğin seçilme, sıralanma, sınıflandırma, önceliklendirme veya elenme amacıyla genellikle ağırlıklandırılmış, birbirleri ile çelişen ve aynı ölçü birimini kullanmayan hatta bazıları nitel değerler alan çok sayıda ölçüt kullanılarak değerlendirilmesi işlemidir (Yoon ve Hwang 1995). Karar verme, genel olarak seçenek kümesinden, en az bir amaç doğrultusunda ve bir kritere dayanarak en uygun, mümkün bir ya da birkaç seçeneği seçme sürecidir. Buna göre karar verme süreci karar verici, seçenekler, kriterler, çevresel etkiler, karar vericinin öncelikleri ve kararın sonuçları elemanlarını içerir. Karar verme süreci, karar vericinin mevcut seçenekler arasından bir seçim, sıralama ya da sınıflandırma yapması şeklinde bitebilir (Evren ve Ülengin 1992).

Günümüzde bilimin ve teknolojinin gelişmesine paralel olarak karmaşık yapıdaki problemlerin çözümünde tek ölçütlü analizlerin yeterli olmadığı bilinmektedir. Tek ölçütlü analizlerde en önemli varsayım, modeldeki diğer ölçütlerin etkileri sabit kabul edilerek ve her yinelemede sadece bir ölçütün (faktörün) incelenmesidir. Ancak, gerçekte olaylar ve objeler sadece tek bir faktörün etkisi ile değil, çok sayıda iç ve dış faktörün ortak etkisi ile oluşmakta ve karmaşık bir yapı göstermektedir. Bu nedenle olaylar ve objeler çok değişkenli yorumların ortaklaşa etkilerine göre tanımlanmalıdır (Özcan vd. 2007).

Çok Kriterli Karar Verme yöntemlerini kullanmaktaki amaç, alternatif ve parametre (kriter) sayılarının fazla olduğu durumlarda karar verme mekanizmasını kontrol altında tutabilmek ve karar sonucunu mümkün olduğu kadar kolay ve çabuk elde etmektir (Öztürk 2009). Seçimde ulaşılmak istenen hedefi birçok parametrenin belirlediği ve seçim için değerlendirilecek alternatiflerin her birinin kendine has avantajlarının bulunduğu durumlarda karar verme işi çok zor bir durum alacaktır. Böyle durumlarda kararı verecek olan kişi ya tüm bu kararsızlık sıkıntısından kurtulmak için, sağlıklı olup olmadığını önemsemeden, bir karara varacak; ya da uzun ve rasyonel olmayan analizler sonunda kuşku içerisinde bir karara varacaktır. CBS ile entegre edilebilen birçok "Çok Kriterli Karar Verme" yöntemi bulunmaktadır. Bu yöntemler;

- Basit Ağırlıklı Toplam Yöntemi (Simple Additive Weighting Method - SAW) ya da diğer adıyla Ağırlıklı Doğrusal Birleştirme (Weighted Linear Combination - WLC)

- Ağırlıklı Çarpım Yöntemi (Weighted Product Method - WPM)

- Analitik Hiyerarşi Yöntemi (Analytic Hierarchy Process - AHP)

- Değer/Fayda Fonksiyonu Yaklaşımı (Value/Utility Function Approach)

- İdeal Nokta Yöntemi (Ideal Point Method - Örn: TOPSIS)

- Uyum Yöntemi (Concordance Method - Örn: ELECTRE)

- Bulanık Mantık İşlemi (Fuzzy Aggregation Operation)

- Bulanık Ağırlıklı Toplam Yöntemi (Fuzzy Additive Weighting Method)

- Sıralı Ağırlıklı Ortalama (Ordered Weighted Average - OWA) şeklindedir.

Yapılan çalışmada etkilenebilirlik analizi; havzanın dijital yüzey modeli, eğim, bakı, jeolojik özellikler, arazi kullanımı/örtüsü olmak üzere 5 parametreye bağlı AHP yöntemi ile gerçekleştirilmiştir.

\subsubsection{Analitik Hiyerarşi Yöntemi (AHP)}

AHP, belirlilik ya da belirsizlik altında çok sayıda alternatif arasından seçim yaparken, çok sayıda karar vericinin bulunduğu, çok kriterli, çok amaçlı bir karar verme durumunda kullanılır. Her sorun için amaç, kriter, olası alt kriter seviyeleri ve seçeneklerden oluşan hiyerarşik bir model kullanan AHP, karar hiyerarşisinin tanımlanabilmesi durumunda kullanılan, kararı etkileyen faktörler açısından karar noktalarının yüzde dağılımlarını veren bir karar verme ve tahminleme yöntemi olarak açıklanabilir. 
AHP bir karar hiyerarşisi üzerinde, önceden tanımlanmış bir karşılaştırma skalası kullanılarak, gerek kararı etkileyen faktörler ve gerekse bu faktörlerin karar noktalarının önem değerleri açısından, birebir karşılaştırmalara dayanmaktadır. Sonuçta önem farklılıkları, karar noktaları üzerinde yüzde dağılıma dönüşmektedir (Yaralığlu 2004). Bir karar verme probleminin AHP ile çözümlenebilmesi için gerçekleştirilmesi gereken aşamalar aşağıda tanımlanmıştır.

Adım 1: Karar verme problemini tanımlama: Karar verme probleminin tanımlanması, iki aşamadan oluşturulur. Birinci aşamada karar noktaları saptanır. Diğer bir deyişle "karar kaç sonuç üzerinden değerlendirilecektir?" sorusuna cevap aranır. İkinci aşamada ise karar noktalarını etkileyen faktörler saptanır. Bu çalışmada karar noktalarının sayısı m, karar noktalarını etkileyen faktör sayısı ise $n$ ile sembolize edilmiştir. Özellikle sonucu etkileyecek faktörlerin sayısının doğru belirlenmesi ve her bir faktörün detaylı tanımlarının yapılması, ikili karşılaştırmaların tutarlı ve mantıklı yapılabilmesi açısından önemlidir.

Adım 2: Faktörler arası karşılaştırma matrisi oluşturma: Faktörler arası karşılaştırma matrisi, nxn boyutlu bir kare matristir (1). Karşılaştırma matrisinin köşegeni üzerindeki bileşenler, yani $i=j$ olduğunda, 1 değerini alır. Çünkü bu durumda ilgili faktör kendisi ile karşılaştırılmaktadır. Faktörlerin karşılaştırılması, birbirlerine göre sahip oldukları önem değerlerine göre birebir ve karşılıklı yapılır. Faktörlerin birebir karşılıklı karşılaştırılmasında Tablo 2'deki önem skalası kullanilır.

$$
A=\left[\begin{array}{cccc}
a_{11} & a_{12} & \ldots & a_{1 n} \\
a_{21} & a_{22} & \ldots & a_{2 n} \\
\cdot & & & \cdot \\
\cdot & & & \cdot \\
\cdot & & & \cdot \\
a_{n 1} & a_{n 2} & \ldots & a_{n n}
\end{array}\right]
$$

Örneğin; birinci faktör üçüncü faktöre göre karşılaştırmayı yapan tarafından daha önemli görünüyorsa, bu durumda karşılaştırma matrisinin birinci satır üçüncü sütun bileşeni 3 değerini alacaktır $(i=1, j=3)$. Aksi durumda yani birinci faktörün üçüncü faktörle karşılaştırılmasında, daha önemli tercihi üçüncü faktörden yana kullanılacaksa bu durumda karşılaştırma matrisinin birinci satır üçüncü sütun bileşeni 1/3 değerini alacaktır. Aynı karşılaştırmada birinci faktörle üçüncü faktörün karşılaştırılmasında faktörler eşit öneme sahip oldukları yönünde tercih kullanılıyorsa bu durumda bileşen 1 değerini alacaktır.

Tablo 2: Önem Skalası

\begin{tabular}{cl}
\hline Önem Değerleri & Değer Tanımları \\
\hline 1 & Her iki faktörün eşit öneme sahip olması durumu \\
3 & 1. Faktörün 2. faktörden daha önemli olması durumu \\
5 & 1. Faktörün 2. faktörden çok önemli olması durumu \\
7 & 1. Faktörün 2. faktöre nazaran çok güçlü bir öneme sahip olması durumu \\
9 & 1. Faktörün 2. faktöre nazaran mutlak üstün bir öneme sahip olması durumu \\
$2,4,6,8$ & Ara değerler \\
\hline
\end{tabular}

Karşılaştırmalar, karşılaştırma matrisinin tüm değerleri 1 olan köşegeninin üstünde kalan değerler için yapılır. Köşegenin altında kalan bileşenler için ise aşağıdaki formülü kullanmak yeterli olacaktır.

$$
a_{j i}=\frac{1}{a_{i j}}
$$

Adım 3: Faktörlerin yüzde önem dağılımları belirleme: Karşılaştırma matrisi, faktörlerin birbirlerine göre önem seviyelerini belirli bir mantık içerisinde gösterir. Ancak bu faktörlerin bütün içerisindeki ağırlıklarını, diğer bir deyişle yüzde önem dağılımlarını belirlemek için, karşılaştırma matrisini oluşturan sütun vektörlerinden yararlanılır ve $n$ adet ve $n$ bileşenli $B$ sütun vektörü oluşturulur (3). 
$B_{i}=\left[\begin{array}{c}b_{11} \\ b_{21} \\ \cdot \\ \cdot \\ b_{n 1}\end{array}\right]$

$B$ sütun vektörlerinin hesaplanmasında aşă̆ıldaki formülden yararlanılır.

$$
b_{i j}=\frac{a_{i j}}{\sum_{i=1}^{n} a_{i j}}
$$

Yukarıda anlatılan adımlar diğer değerlendirme faktörleri içinde tekrarlandığında faktör sayısı kadar $B$ sütun vektörü elde edilecektir. $n$ adet $B$ sütun vektörü, bir matris formatında bir araya getirildiğinde ise aşağıda gösterilen $C$ matrisi oluşturulacaktır (5).

$$
C=\left[\begin{array}{cccc}
c_{11} & c_{12} & \ldots & c_{1 n} \\
c_{21} & c_{22} & \ldots & c_{2 n} \\
\cdot & & & \cdot \\
\cdot & & & \cdot \\
\cdot & & & \cdot \\
c_{n 1} & c_{n 2} & \ldots & c_{n n}
\end{array}\right]
$$

$C$ matrisinden yararlanarak, faktörlerin birbirlerine göre önem değerlerini gösteren yüzde önem dağılımları elde edilebilir. Buna göre $C$ matrisini oluşturan satır bileşenlerinin aritmetik ortalaması alınır ve öncelik vektörü olarak adlandırılan $W$ sütun vektörü elde edilir (6).

$$
w_{i}=\frac{\sum_{j=1}^{n} c_{i j}}{n}
$$

$W$ vektörü aşağıda gösterilmiştir (7).

$$
W=\left[\begin{array}{c}
w_{1} \\
w_{2} \\
\cdot \\
\cdot \\
w_{n}
\end{array}\right]
$$

Adım 4: Her bir faktör için, " $m$ ” karar noktasındaki yüzde önem dağılımı bulma: Bu aşamada, her bir faktör açısından karar noktalarının yüzde önem dağılımları belirlenir. Diğer bir deyişle birebir karşılaştırmalar ve matris işlemleri, faktör sayısı kadar (n kez) tekrarlanır. 
Ancak bu kez her bir faktör için karar noktalarında kullanılacak karşılaştırma matrislerinin boyutu mxm olacaktır. Her bir karşılaştırma işleminden sonra $m x l$ boyutlu ve değerlendirilen faktörün karar noktalarına göre yüzde dağılımlarını gösteren $S$ sütun vektörleri elde edilir (8).

$$
S_{i}=\left[\begin{array}{c}
s_{11} \\
s_{21} \\
\cdot \\
\cdot \\
\cdot \\
s_{m 1}
\end{array}\right]
$$

Adım 5: Karar noktalarındaki sonuç dağılımını bulma: Bu aşamada öncelikle, yukarıda anlatılan $n$ tane $m x l$ boyutlu $S$ sütun vektöründen meydana gelen ve $m x n$ boyutlu $K$ karar matrisi oluşturulur (9).

$$
K=\left[\begin{array}{cccc}
s_{11} & s_{12} & \ldots & s_{1 n} \\
s_{21} & s_{22} & \ldots & s_{2 n} \\
\cdot & & & \cdot \\
\cdot & & & \cdot \\
\cdot & & & \cdot \\
s_{m 1} & s_{m 2} & \ldots & s_{m n}
\end{array}\right]
$$

Sonuçta karar matrisi W sütun vektörü (öncelik vektörü) ile aşağıdaki gibi çarpıldığında ise $m$ elemanlı $L$ sütun vektörü elde edilir (10). L sütun vektörü karar noktalarının yüzde dağılımını verir. Diğer bir deyişle vektörün elemanlarının toplamı 1'dir. Bu dağılım aynı zamanda karar noktalarının önem sırasını da gösterir.

$$
L=\left[\begin{array}{cccc}
s_{11} & s_{12} & \ldots & s_{1 n} \\
s_{21} & s_{22} & \ldots & s_{2 n} \\
\cdot & & & \cdot \\
\cdot & & & \cdot \\
\cdot & & & \cdot \\
s_{m 1} & s_{m 2} & \ldots & s_{m n}
\end{array}\right] x\left[\begin{array}{c}
w_{1} \\
w_{2} \\
\cdot \\
\cdot \\
\cdot \\
w_{n}
\end{array}\right]=\left[\begin{array}{c}
l_{11} \\
l_{21} \\
\cdot \\
\cdot \\
\cdot \\
l_{m 1}
\end{array}\right]
$$

\subsection{Hidrolik Modelleme Yöntemi}

Hidrolojik sistemin rasgele karakteri, hidrolojik verilerdeki örnekleme hataları ve hidrolojik süreç için kabul edilen modeldeki hatalar hidrolojik değişkenlerin rasgele nitelik taşımasına neden olur. Bir hidrolojik büyüklüğün rasgele değişkenliği önemli değilse bu yanı ihmal edilip ortalama değeri ile çalışılarak olay deterministik bir yaklaşımla incelenebilir. Ancak taşkın debisi gibi bazı büyüklükler için böyle bir yaklaşım anlamlı olmamaktadır. Bu durumda olasılık teorisi ve istatistik bilimlerine dayanan olasılık dağılım modellerinden yararlanılır (Bayazıt 1998). Taşkın debisi dağılım modelleri, hidrolojik tasarımda özel bir önem taşıyan taşkın debileri için uygun dağılım fonksiyonlarının belirlenmesi ve bunlarla proje dönüş aralığına karşı gelen taşkın debisinin tahmini için geliştirilen modellerdir.

Hidrolik yapıların tasarlanması, su kaynakları sistemlerinin yönetimi ve taşkın ötelenmesi gibi mühendislik aktivitelerinde taşkın karakteristiklerinin doğru tahminleri gerekmektedir. Eğer gereğinden büyük tahmin yapılmışsa maliyette önemli artışlar, eksik tahmin yapılmışsa can ve mal kayıpları riski meydana gelebilmektedir. Bu yüzden hidrolojik frekans analizlerinde bir dağılımın verilere uygun olup olmadığı kesin olarak bilinmediği için çeşitli olasslık dağılımları denenerek bunların arasından veriye hem en yakın dağılımı saptamak, hem de yapılan tahminlerin ne denli doğru olduğunun da değerlendirmesinin yapılması çok önemlidir (Anlı 2006). 
Akarsulara ait hidrolik modellemelerin yapılabilmesi için akarsu yataklarına ait geometrik verilere gereksinim vardır (Özdemir 2007). Bu veriler genel olarak; akarsu sistemlerinin bağlantısının kurulmasından, yatak enkesitlerinden, bağlantı noktalarının tanımlanmasından, hidrolik yapılara ait verilerden ve enkesit enterpolasyonlarından oluşmaktadır. Minimum düzeyde kullanılan geometrik veriler ise akarsular, akarsu kıyıları, akış yolları, enkesitler ve arazi kullanımıdır. Öncelikle geometrik verilerin oluşturulmasında altlık veri olarak TIN modelinin oluşturulması gerekmektedir. TIN üretiminden sonra, modellemesi yapılacak alan içindeki geometrik verilerin dijitalleştirilmesi ve veri girişi işlemleri yapılması gerekmektedir.

$\mathrm{Bu}$ verilerin dijitalleştirilmesinde TIN modelinden, yüksek çözünürlüklü uydu görüntülerinden ve hava fotoğraflarından ya da günümüzde gittikçe kullanımı artan insansız hava araçlarından elde edilen çok yüksek çözünürlüklü fotoğraflardan yararlanılabilinir. Geometrik verilerin dijitalleştirilmesinde ve veri girilmesinde dikkat edilen bazı özellikler aşağıda belirtilmiştir;

- Akarsular, akarsu kıyıları ve akış yolları akarsuyun akış yönüne doğru dijitalleştirilmelidir.

- Akış yollarının tanımlamaları yapılmalıdır (să̆, sol ve merkez).

- Yatak en kesit çizgileri akarsu akış yönüne doğru sol kıyıdan sağ kıyıya doğru dijitalleştirilmelidir.

- Arazi kullanım katmanı uydu görüntüsü ile oluşturulduğunda bu katmanda yer alan arazi kullanım türlerine, hidrolik olarak akıma karşı sergilediği davranışın bir göstergesi olarak kabul edilen Manning's $N$ değeri atanması gerekmektedir (Fleckkenstein 1998; Özcan 2007).

\subsection{Bilgi Difüzyon Teorisi}

Bilgi Difüzyonu Teorisi, imkân dâhilinde belli başlı yararlı verileri örneklerden çıkartmaya yardımcı olup, sistem kabulünün doğruluğunu iyileştirmektedir (Huang 2002; Palm 2007). Bu teoride, tek değerli örnek bir dizi, sayısal değerli bir örneğe dönüştürülür. Bu tür modellerin en basiti normal difüzyon modeli ise aşağıdaki şekilde işler. Taşkın hasar indeks alanının şu şekilde gösterildiğini düşünelim;

$$
U=\left\{u_{1}, u_{1}, \ldots ., u_{n}\right\}
$$

Tek değerli gözlem örneğinin, $y_{j}$, taşıdığı bilgi $U$ alanının her noktasına yayılması aşağıdaki eşitlik ile ifade edilir;

$$
f_{j}\left(u_{i}\right)=\frac{1}{h \sqrt{2 \pi}} e^{-\frac{\left(y_{j}-u_{i}\right)^{2}}{2 h^{2}}}
$$

Formüldeki $h$ difüzyon sabiti olup, maksimum $b$ ve minimum $a$ değerlerine binaen belirlenir ve örnek setleri içindeki örnekleme sayısı $m$ ile şu şekilde ilişkilendirilir;

$$
h= \begin{cases}1.4230(b-a) /(m-1) & m<10 \\ 1.4208(b-a) /(m-1) & m \geq 10\end{cases}
$$

Bulanık altkümenin ilgili bağlantı fonksiyonu aşağıdaki eşitlikte gösterildiği şekilde olacaktır.

$$
\mu_{y_{j}}\left(u_{i}\right)=f_{j}\left(u_{i}\right) / \sum_{i=1}^{n} f_{j}\left(u_{i}\right)
$$

$\mu_{y_{j}}\left(u_{i}\right)$ fonksiyonu $y_{j}$ 'nin normalize edilmiş bilgi dağılımı olarak ifade edilir. İyi bir sonuç üreten risk analizi için aşağıdaki formülü uygulamamız gereklidir.

$$
q\left(u_{i}\right)=\sum_{j=1}^{m} \mu_{y_{j}}\left(u_{i}\right)
$$

Üstteki fonksiyonun fiziksel anlamı; eğer taşkın hasarının gözlem değeri $u_{1}, u_{2}, \ldots, u_{n}$ serisinin birinden seçiliyorsa, örnekleme sayısı $u_{i}$ 'nin gözlem değeri ile birlikte $q\left(u_{i}\right)$ olarak sunulur. Bu değer sıfırdan küçük olmamak şartı ile pozitif bir tamsayı olmayacaktır. $Q$ değeri $u_{i}$ 'deki her bir örnekleme değerinin toplamına eşittir. 


$$
Q=\sum_{i=1}^{n} q\left(u_{i}\right)
$$

Buna göre $u_{i}$ noktasındaki örneğin frekans değeri aşağıdaki gibi hesaplanır ve bu değer olasıllı̆̆ın hesaplanmış değeri olarak kullanılır.

$$
p\left(u_{i}\right)=q\left(u_{i}\right) / Q
$$

Buna göre aşağıdaki formüldeki $p\left(u \geq u_{i}\right)$ notasyonu, risk değerlendirmesi için gereken değerdir (Chang vd. 2007).

$$
p\left(u \geq u_{i}\right)=\sum_{k=1}^{n} p\left(u_{k}\right)
$$

\subsection{SCS-CN (Soil Conservation Service Curve Number) Yöntemi}

Yeryüzüne yağışlarla düşen suyun büyük bir kısmı zeminden ve su yüzeylerinden buharlaşma ile atmosfere geri dönmekte, bir kısmı bitkiler tarafından tutulmakta, bir kısmı da zeminden sızarak yeraltına geçmektedir. Geriye kalanı ise yüzeysel akış olarak yerçekimi etkisiyle hareket ederek akarsulara ve sonra denize ulaşmaktadır (Bayazıt 1998). Akış oranı, sel ve taşkın oluşumunu doğrudan etkilemekte, yüksek akış olan alanlarda sel ve taşkın oluşumu da artmaktadır (Özdemir 1978; Özer 2008).

ABD Toprak Koruma Kurumu (U.S. Soil Conservation Service - SCS) tarafından yağış-akış-kayıp ilişsisini analiz etmek üzere 1972 yılında Eğri Numarası (Curve Number - CN) adıyla bir yöntem geliştirilmiştir. SCS-CN olarak adlandırılan bu yöntem, özellikle küçük ölçekli havzalarda akım ölçümleriyle test edilmiş ve yöntemin geçerliliği çok sayıda çalışma ile ortaya konulmuştur. Bu yönteme göre, yağış anında ve sonrasında toprak tarafindan tutulan su, yağışın ve toprak CN'inin fonksiyonudur. $\mathrm{CN}$ değeri toprak türü (hidrolojik toprak grubu), arazi örtüsü ve arazinin kullanımı (teraslama vb.), hidrolojik koşullar ve toprağın önceki nem koşullarına bağlı olarak 0-100 arasında değişmekle birlikte bu değerler çoğunlukla 55-95 arasında olmaktadır (Hawkins 1998). Bilindiği gibi yağış başladığında hemen yüzeysel akış oluşmaz. Akıș oluşana kadar bir miktar su toprak ve bitkiler tarafından tutulur. Toprak ne kadar kuru ise, akış oluşmadan önceki tutulma o kadar fazla olur. Dolayısıyla toprağın yağış başladığındaki nem içeriği, süzülme ve yüzeysel akış mekanizmasında son derece önemlidir. Yağışla birlikte toprağın nem içeriği arttıkça süzülme hızı azalır ve en sonunda sabit bir değere ulaşır. Bu değer, toprağın en düşük süzülme kapasitesidir.

SCS-CN yöntemi, yağış verilerinden akışın belirlenmesinde sıkça kullanılan bir yöntemdir. Akışı elde etmek için gerekli veriler; yağış, hidrolojik toprak sınıfları ve arazi kullanımı/örtüsüdür. Bu yönteme göre, düşen yağı̧ ile oluşan yüzey akış arasında aşağıdaki eşitlikle ifade edilen bir ilişki vardır.

$$
\frac{F}{S}=\frac{Q}{P-I_{a}}
$$

Burada, $F$ sızma miktarı (mm), $S$ potansiyel maksimum yağış tutulması $(\mathrm{mm}) ; Q$ eklenik yüzey akış miktarı $(\mathrm{mm}) ; P$ eklenik yağı̧ miktarı $(\mathrm{mm})$ ve $I_{a}$ başlangıçta tutulan yağış miktarı $(\mathrm{mm})$ 'dır. Ayrıca süreklilik prensibinden,

$$
P=Q+I_{a}+F
$$

eşitliği de yazılabilir. Burada başlangıçta tutulan yağış miktarının,

$$
I_{a}=0.2 S
$$

olması halinde ve yukarıda verilen yukarıdaki eşitliklerin birlikte çözümü sonucu, $P>I_{a}$ koşulu için aşağıdaki yüzey akış miktarı,

$$
Q=\frac{\left(P-I_{a}\right)^{2}}{P-I_{a}+S}
$$

elde edilmektedir. 
Eşitlikte yer alan potansiyel maksimum yağış tutulması, aşağıdaki eşitlik kullanılarak havza yüzey akış eğri numarasından hesaplanmıştır.

$$
S=\frac{2540}{C N}-25.4
$$

$\mathrm{CN}$; havzaya ait toprak, topografya, arazi kullanma, bitki örtüsü, ekim şekli ve toprak koruma önlemlerinin dikkate alınarak belirlendiği, 0 ile 100 arasında değişen bir sayıdır. Burada 100 değeri su yüzeyini temsil etmekte olup, diğer yüzey değerleri 100'den küçük sayılardır. Bu eğri numarası, üç sınıfa ayrılmış önceki toprak nem koşulundan (Antecedent Moisture Condition - AMC), AMC II, diğer bir ifadeyle CN II içindir. Yüzey akışı hesaplanan yağış öncesi 30 gün içerisinde düșen yağıș miktarı 36-53 mm arasında olması CN II, bundan küçükse CN I ve büyükse CN III olmaktadır (Boonstra 1994). Önceki 30 günlük toprak nem içeriğinin bir diğerine dönüştürülmesinde aşağıdaki eşitlikler kullanılmıştır (SCS 1975; Chow vd. 1988).

$$
\begin{aligned}
& C N I=\frac{4.2 C N I I}{10-0.058 C N I I} \\
& C N I I I=\frac{23 C N I I}{10+0.13 C N I I}
\end{aligned}
$$

Ayrıca SCS-CN yönteminde, 30 günlük toprak nem içeriğinin dikkate alındığı ve alınmadığı koşullar ile havzadan ölçülen doğrudan yüzey akış değerleri; havza $\varphi$-sızma indisi (Linsley vd. 1989) ve evapotranspirasyon (Doorenbos ve Pruitt 1977) değerleri ile karşılaştırılmıştır. Bu anlamda yağış değerlerinin bağımsızlık ve homojenlik testleri ile tüm verilerin istatistiki analizleri Chow vd. (1988)'de belirtildiği esaslara göre yapıllmıştır (Şekil 1).

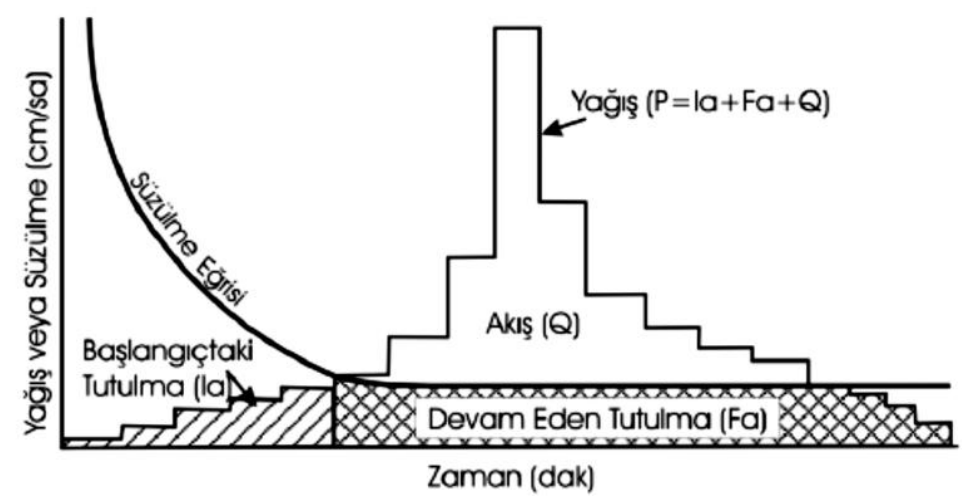

Şekil 1: Süzülme-tutulma ve yağış fazlası ilişkileri (Chow vd.1988; Apaydın 2004a ve 2004b'den). Q: Yüzey akış miktarı (mm), P: Yağış miktarı (mm), S: Potansiyel maksimum yağış tutulması (mm), CN: Yüzey akış eğri numarası, F: Sızma miktarı $(\mathrm{mm})$, la: Başlangıçta tutulan yağış miktarı $(\mathrm{mm})$

Bağıntılarda yer alan $\mathrm{CN}$, hidrolojik toprak grupları ve arazi kullanımı/örtüsü bilgilerine göre elde edilmektedir. Buna göre, havzadaki yerleşim yerlerinin sahip oldukları toprak grupları türüne göre aldığı CN değerleri, bölgenin arazi kullanım/örtüsü ile işleme alınmış, günlük yağış değerlerinden toprağın nem içeriğine göre hangi CN koşulunun geçerli olacağı belirlenmiştir (Tablo 3).

Tablo 3: Ayamama Deresi için CN değerleri

\begin{tabular}{cccc}
\hline Havza & CNI & CNII & CNIII \\
\hline Ayamama Havzası & 49 & 69.58 & 84.03 \\
\hline
\end{tabular}




\section{Değerlendirme ve Bulgular}

\subsection{Etkilenebilirlik Analizi}

AHP yöntemiyle etkilenebilirlik analizi için sayısal yükseklik modeli, bu sayısal yükseklik modelinden elde edilmiş eğim ve bakı haritaları, arazi kullanımı haritası, stratigrafi ve yapısal jeoloji haritası olmak üzere beş adet veri kullanılmıştır. AHP ilgili kriterler temelinde karar vericinin verdiği hükümlere bağlı olarak ilgili karar seçeneklerini sıralar. Uygulanan yöntemde etkilenebilir alanlar belirlenirken parametreler tek tek ele alınmıştır. Havza için gerçekleştirilen etkilenebilirliğe ait temel elemanları, havzanın coğrafi özellikleri ile taşkın karakteristikleri oluşturmaktadır. Yöntemin akış şeması Şekil 2'de ayrıntılı olarak verilmiştir.

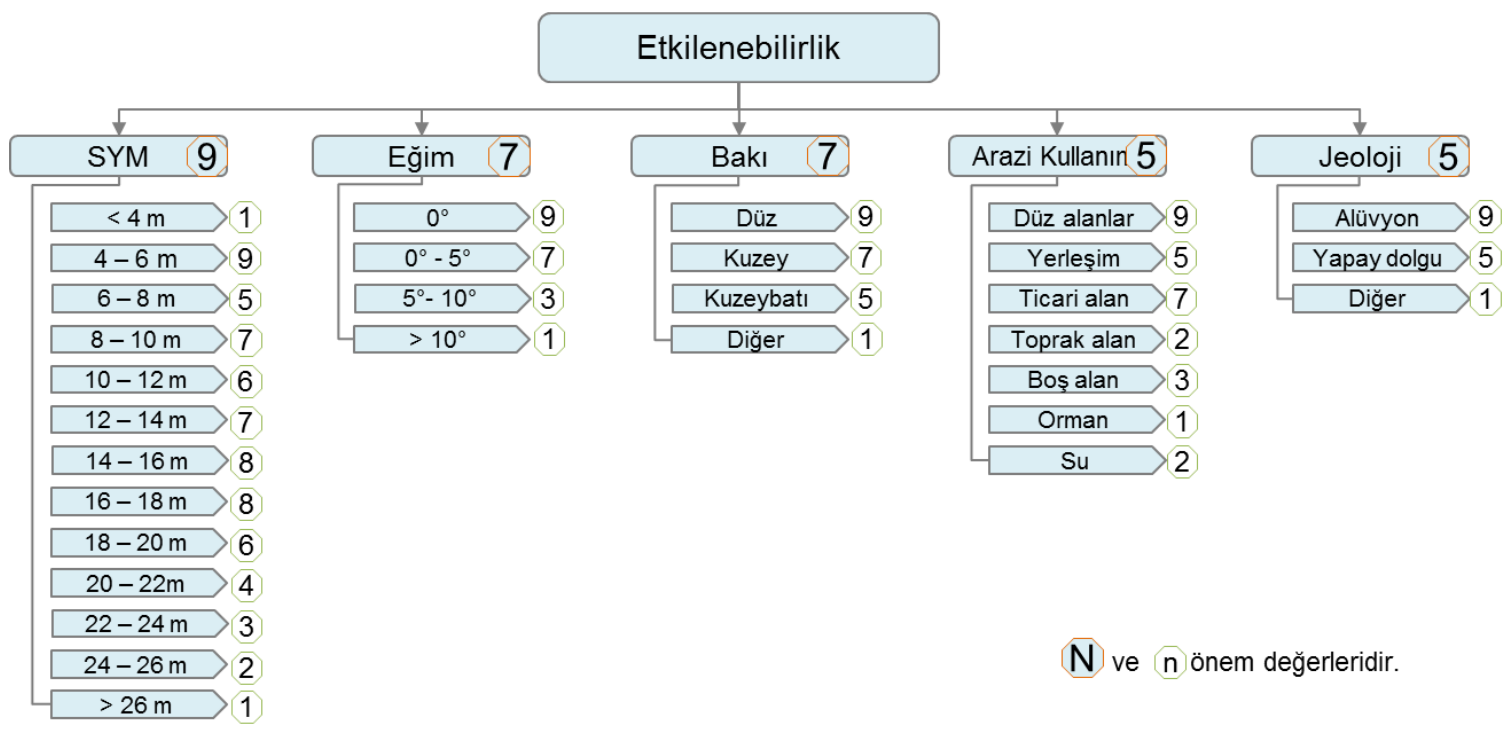

Şekil 2: Etkilenebilirlik analizi akış şeması

İstanbul'un Avrupa yakasının 2.5 metre çözünürlüklü SPOT-5 uydu görüntüsünden elde edilen sayısal yükseklik modelinden, Ayamama Deresi havzası çıkarılmış ve bu SYM'den arazinin eğim ve bakı değerleri elde edilmiştir. Çalışma alanına ait arazi kullanımı verisi ise yine 2.5 metre çözünürlüklü SPOT 5 uydu görüntüsünden elde edilerek girdi olarak kullanılmıştır. Çalışma bölgesi için taşkın duyarlılığı, bütün bu kriterler ve bu kriterlerin sahip olduğu alt kriterlerin ağırlıklandırılmasıyla (önem değerleri) hesaplanmıştır.

Uygulanan çok kriterli karar verme yönteminde, parametrelerin ilgili afetlere olan etkileri farklı oranda olması dolayısıyla her birine farklı değerler girilmiştir. Üst üste bindirme işlemi gerçekleştirilerek etkilenebilirlik haritası oluşturulmasında en mantıklı ve güvenilebilir sonuç, çalışma alanının fiziksel parametrelerine bağlı olarak yapılan farklı yorumlamalara ve buna bağlı olarak verilen değerlere göre bulunmuştur (Şekil 3).

Oluşturulan etkilenebilirlik haritasına göre toplamda 1995 binanın etkilenebilir alanlar içerisinde bulunduğu ve bunların 420'sinin çok yüksek etkilenebilir alanlarda olduğu belirlenmiştir. Bunlardan 287'si işyeri ve 143' ü meskûn binalar olmak üzere dere yatağına çok yakın olmaları nedeniyle yüksek risk taşımaktadır. 09.09.09 tarihinde gerçekleşen taşkın 3816 konut ve 1490 işyerinin zarar görmesine neden olmuştur (Kirmencioğlu 2015).

\subsection{Taşkın Modellemesi}

Hidrolik Modelleme uygulaması ile taşkın modellemesi için Şekil 4'deki akış şeması oluşturulmuştur. Modelleme çalışmasında öncelikle havza parametrelerinin belirlenmesinde, $2 \mathrm{~m}$ çözünürlüklü grid yapılı sayısal arazi modelinden yararlanılmıştır. Havzanın drenaj ağı çıkartılarak havza sınırı belirlenmiştir. Şekil 5'de gösterildiği şekilde $2.5 \mathrm{~m}$ çözünürlüklü SPOT 5 uydu görüntüsü kullanılarak geometrik veriler oluşturulmuş ve obje-tabanlı en yakın komşuluk sınıflandırması yapılarak görüntü ile her bir en kesitteki Manning pürüzlülük katsayıları belirlenerek modele girdi parametresi olarak eklenmiştir (Melesse vd. 2003). 


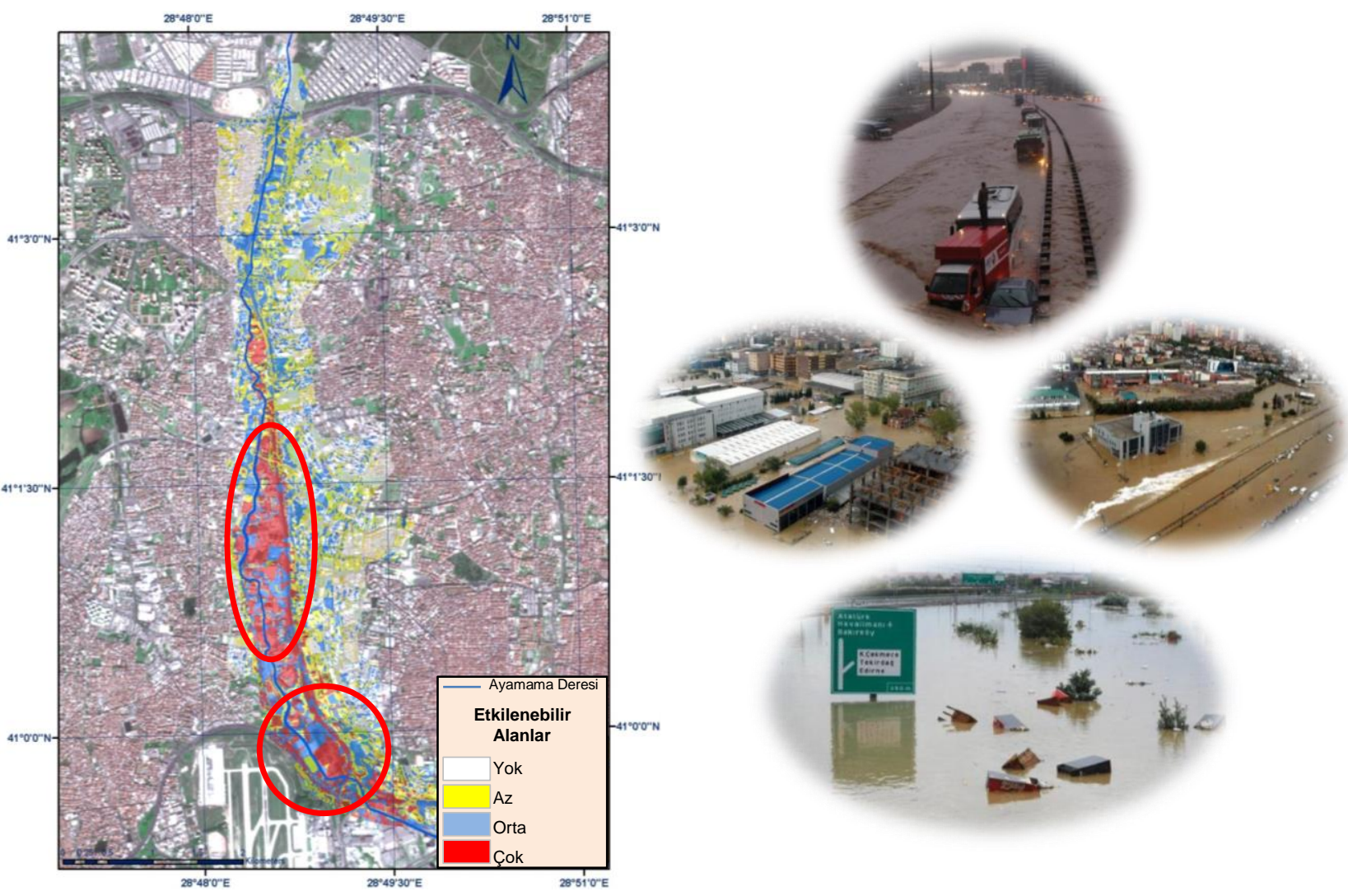

Şekil 3: Yöntemin uygulanmasıyla oluşturulan etkilenebilirlik haritası (solda) ve 09.09.09 tarihinde gerçekleşen taşkının nehir yatağı ile bağlantı yolu üzerinde bulunan binalara etkisi (sağda)

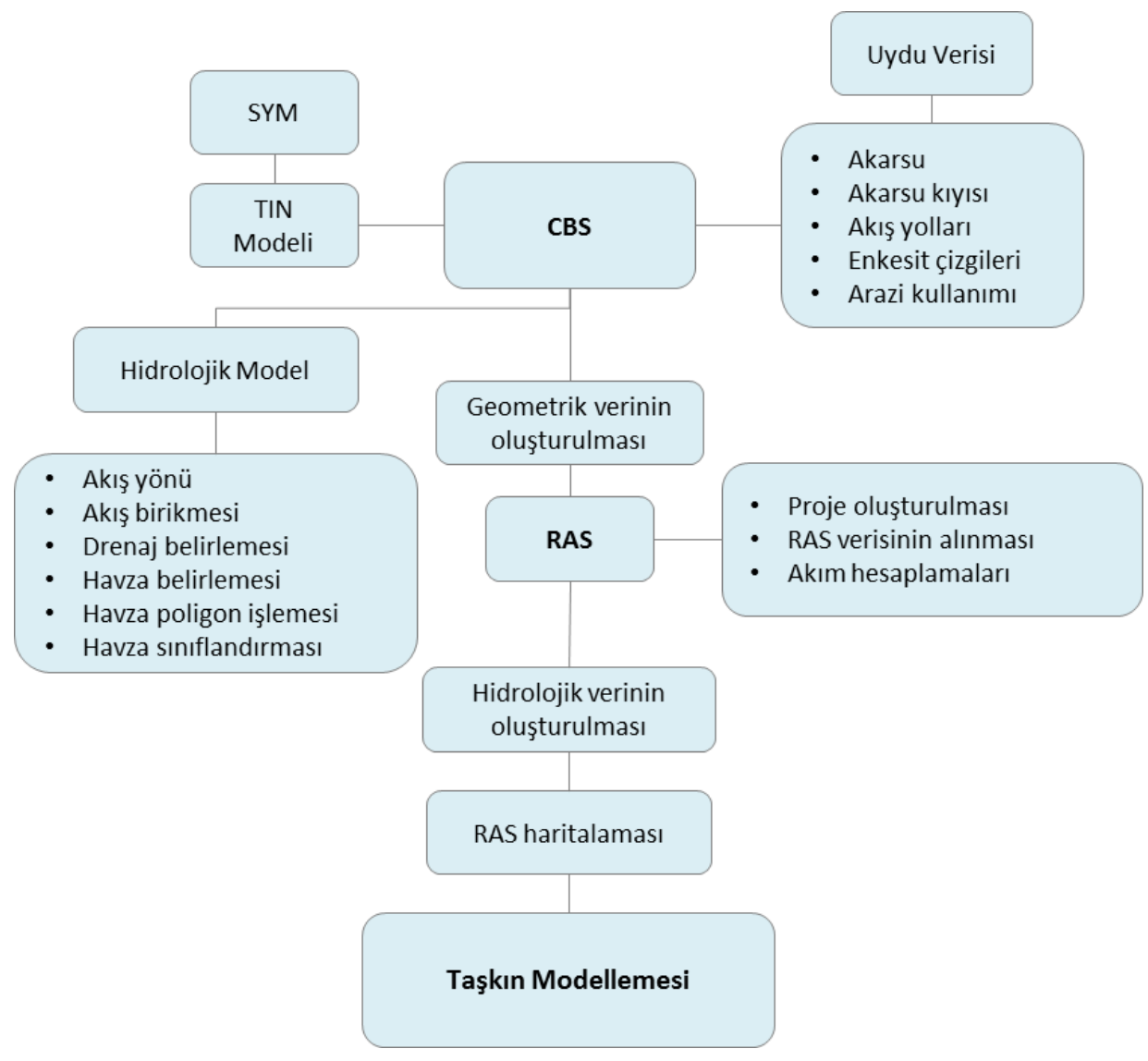

Şekil 4: Hidrolik model uygulamasının akış şeması 
Havza parametreleri HEC_RAS yazılımı ile modellenerek sisteme entegre edilmiş, maksimum akım verileri kullanılarak taşkın modellemesi $\mathrm{CBS}$ ortamında değerlendirilmiş, 3 boyutlu model üzerinde görselleştirme ve analizler gerçekleştirilmiştir (Şekil 6).

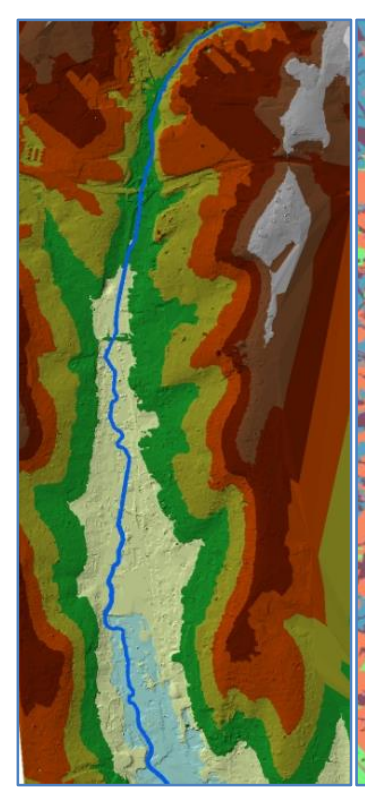

(a)

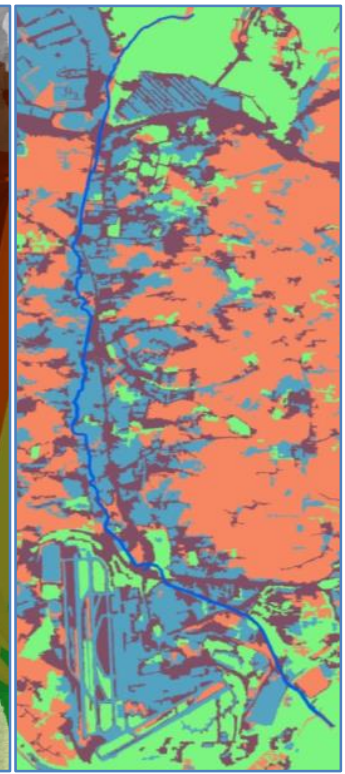

(b)

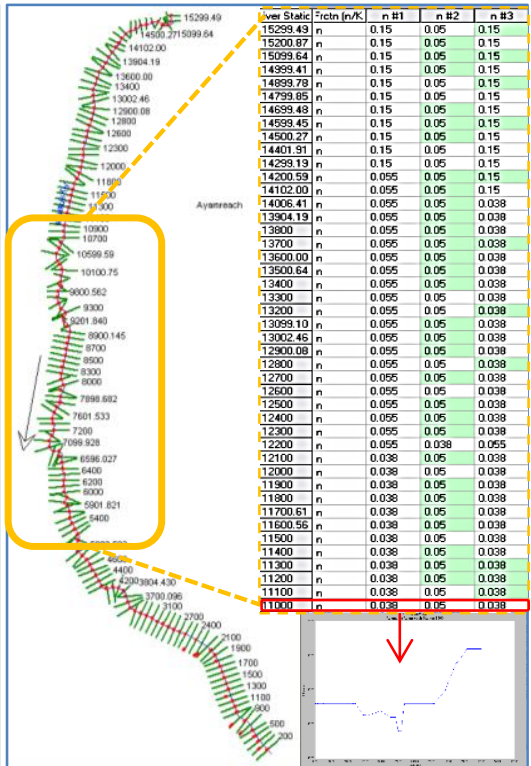

(c)

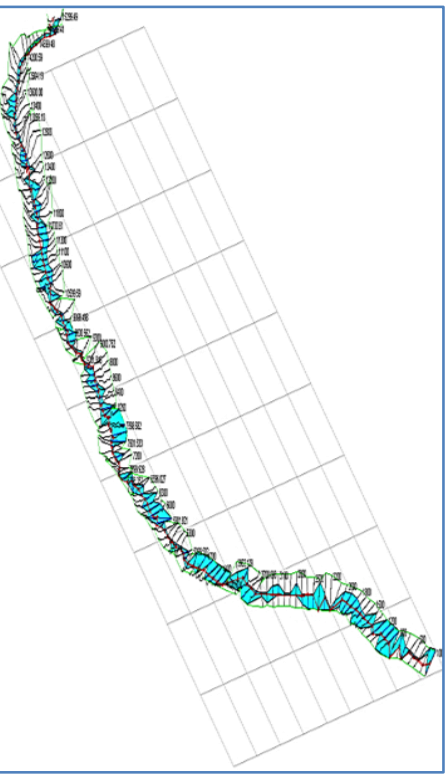

(d)

Şekil 5: Taşkın modellemesi için kullanılan (a) havza alanı SYM, (b) obje-tabanlı sınıflandırılmış veri, (c) enkesitler, Manning katsayıları ve profil örneği, (d) 3-B akış modeli

Hidrolik Modelleme ile Ayamama Deresi için belirlenen akım değerine göre yapılan modelleme sonucu Şekil 6'da gösterildiği üzere $185 \mathrm{~m}^{3} / \mathrm{s}^{\prime}$ lik kararlı akımın yaklaşık olarak 73 ha'lık bir alanı etkileyeceğini göstermiş ve etkilenecek alanlar CBS ortamında belirlenmiştir. Yapılan obje-tabanlı en yakın komşuluk sınıflandırma sonucu temel alındığında olası taşkında etkilenebilir alanda toplamda 1859 binanın etkileneceği belirlenmiştir.
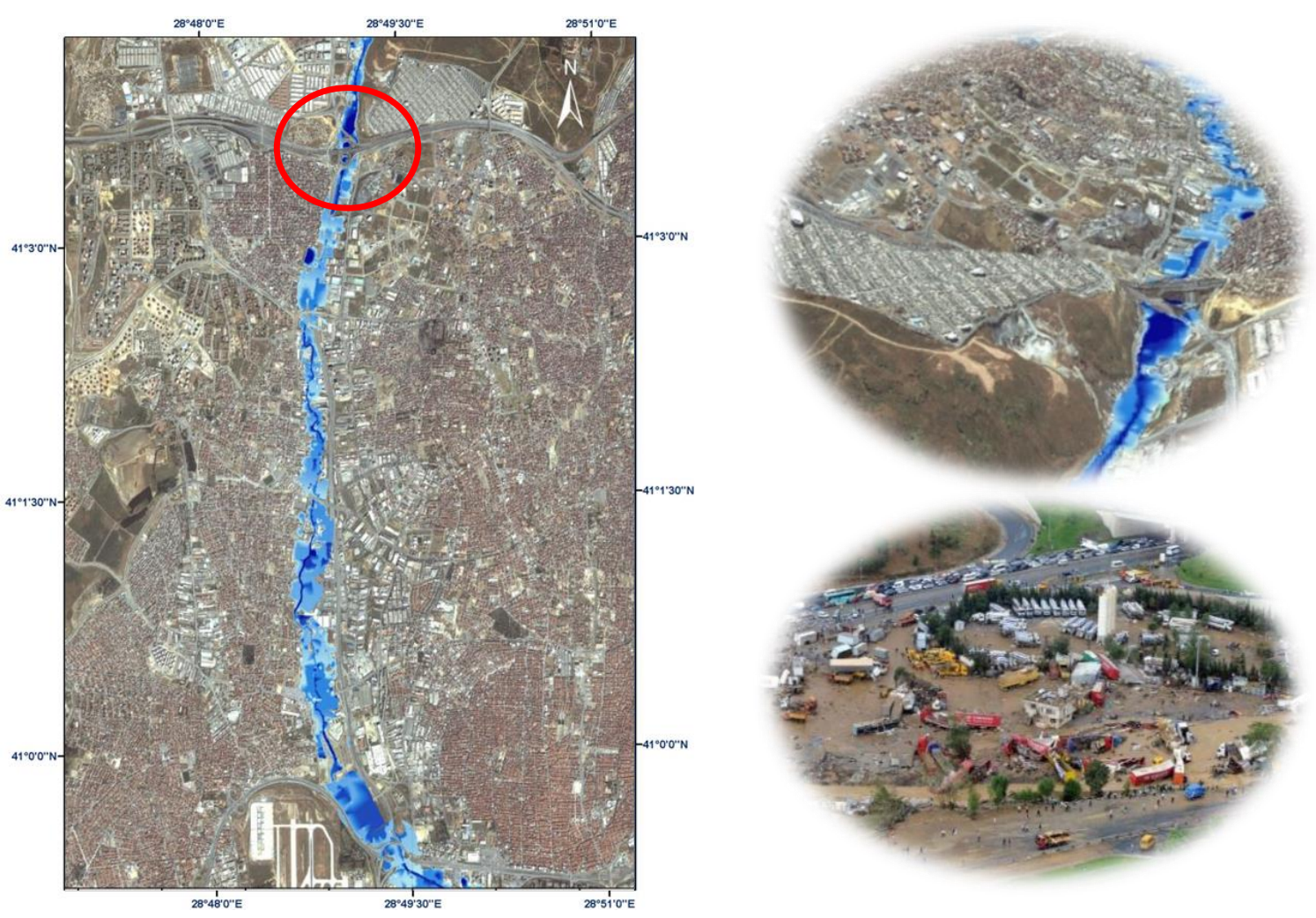

Şekil 6: Modelleme sonucu taşkın alanlarının SPOT 5 uydu görüntüsü üzerinde gösterimi (solda ve sağ üstte) ve 09.09.09 tarihinde gerçekleşen taşkının nehir yatağı ile TEM bağlantı noktasındaki TIR parkına etkisi (sağ altta) 


\subsection{Bilgi Difüzyonu ile Taşkın Risk Analizi}

Bilgi Difüzyonu yöntemi ile taşkın analizi için kullanılan veriler ve akış şeması Şekil 7'de gösterildiği gibi; Ayamama Deresi'nin günlük yağış verileri, nem içerikleri, arazi kullanımı, hidrolojik toprak grupları ve bölgede oluşan geçmiş taşkınların oluşturduğu hasar alanı verileri kullanılmıştır. Çalışma bölgesinin günlük akım verileri, SCS-CN yöntemi yardımıyla günlük yağış verilerinden akım verileri elde edilmiştir (22), (23). Bunun için de yağış verileri, nem içerikleri, hidrolojik toprak grubu ve arazi kullanımı verilerinden faydalanılmıştır. Nem içerikleri, 2009 yılından önceki son dört yılın saatlik nem içerikleri olarak Türkiye Meteorolojik Veri Arşiv Sistemi (TÜMAS)'nden temin edilmiş ve yıllık ortalama bağıl nem hesaplanmıştır. Hidrolojik toprak grupları ise Tarım İl Müdürlüğü’nden elde edilen büyük toprak grupları haritası analiz edilerek çıkartılmıştır.

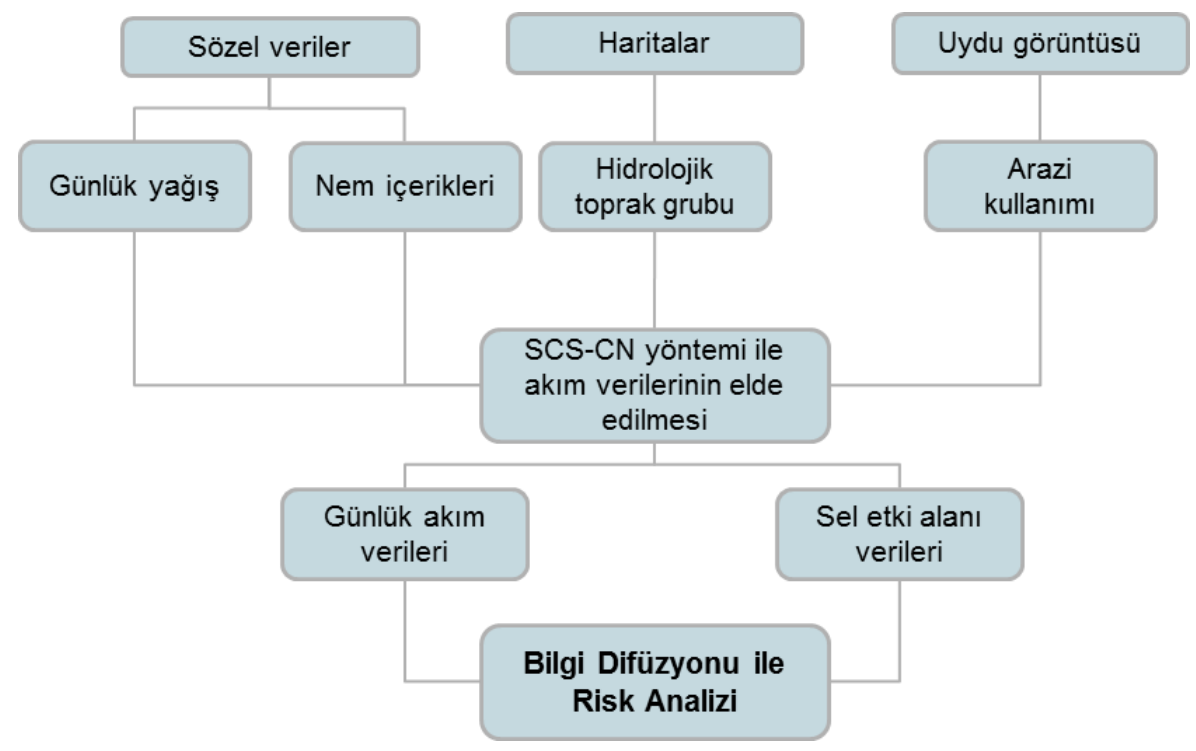

Şekil 7: Bilgi Difüzyonu ile taşkın risk analizi akış şeması.

1975 ile 2009 yılları arasındaki Florya İstasyonu'ndan sağlanan günlük yağış ölçümleri kullanılarak CN değerlerine göre yüzeysel akış miktarları hesaplanarak yıllık maksimum akım verileri belirlenmiş ve geçmiş yıllara ait hasar etki oranları Bilgi Difüzyon yöntemine girdi olarak eklenmiştir (Tablo 4). İleriye yönelik yapılan tahminlerde yıllık maksimum akım verileri kullanılarak taşkın olasılıkları belirlenmiştir.

Tablo 4: Ayamama Deresi 1975 - 2009 yılları arasındaki maksimum debi miktarları (Qm) ve hasar etki oranları (Özcan vd. 2011)

\begin{tabular}{cccccc}
\hline Yll & $\mathbf{Q} \mathbf{m}\left(\mathbf{m}^{\mathbf{3}} \mathbf{s}\right)$ & Hasar & Yll & $\mathbf{Q m}_{\mathbf{m}}\left(\mathbf{m}^{\mathbf{3}} / \mathbf{s}\right)$ & Hasar \\
\hline 08.01 .1975 & 103.72 & 2.25 & 26.02 .1993 & 133.73 & 2.03 \\
14.12 .1976 & 112.73 & 3.00 & 01.08 .1994 & 98.78 & 1.06 \\
22.111977 & 75.04 & 1.00 & 14.01 .1995 & 193.73 & 5.76 \\
30.10 .1978 & 83.57 & 1.52 & 09.09 .1996 & 128.52 & 3.72 \\
24.08 .1979 & 95.73 & 1.72 & 14.10 .1997 & 112.73 & 2.71 \\
15.11 .1980 & 103.73 & 2.40 & 27.10 .1998 & 144.69 & 4.17 \\
01.12 .1981 & 123.34 & 3.06 & 19.11 .1999 & 131.73 & 3.82 \\
30.12 .1982 & 143.73 & 3.20 & 21.02 .2000 & 89.73 & 1.60 \\
21.01 .1983 & 121.94 & 3.31 & 21.11 .2001 & 99.73 & 2.12 \\
12.01 .1984 & 73.73 & 1.00 & 05.01 .2002 & 92.73 & 2.03 \\
28.11 .1985 & 93.27 & 1.70 & 11.11 .2003 & 97.08 & 2.06 \\
02.01 .1986 & 113.73 & 3.10 & 08.10 .2004 & 93.73 & 2.76 \\
10.12 .1987 & 103.73 & 2.27 & 30.01 .2005 & 93.73 & 2.72 \\
25.11 .1988 & 93.75 & 1.60 & 04.11 .2006 & 73.73 & 0.41 \\
26.11 .1989 & 123.73 & 3.20 & 17.11 .2007 & 109.08 & 3.17 \\
10.11 .1990 & 154.73 & 4.24 & 27.10 .2008 & 106.42 & 3.42 \\
07.10 .1991 & 97.13 & 1.78 & 09.09 .2009 & 180.73 & 5.12 \\
21.03 .1992 & 93.73 & 1.11 & & & \\
\hline
\end{tabular}


Tablo 5'de Ayamama Deresi'nin akım miktarları seviyelendirilerek akım seviyesi belirli bir değere ulaştığında, o değere ulaşması için gereken sürenin hesaplanarak bu değerde taşkın olma olasılı̆̆ı ve taşkın olduğunda ne kadarlık bir alana hasar vereceği belirlenmiştir. Çıkarılan sonuçlara göre; Ayamama Deresi’nin akım miktarı $90 \mathrm{~m}^{3} / \mathrm{s}$ değerine yaklaşık olarak 1.1 gün içerisinde erişecektir (1/p). Bu akım değerine ulaştığında taşkın olma olasılığı \%37 olacaktır. Taşkın ortaya çıktığında tahmini olarak \%0.59'luk bir alanda etkili olacak ve yaklaşık 40 hektar alan zarar görecektir. Risk seviyesi değerleri eşitlik (11)'deki $U_{n}$ değerleridir.

Tablo 5: Ayamama Deresi taşkın risk olasılıkları

\begin{tabular}{cccc}
\hline Risk seviyesi & Sonuç (p) & Risk seviyesi & Sonuç (p) \\
\hline 60 & 1.0000 & 135 & 0.2216 \\
75 & 0.9983 & 150 & 0.1277 \\
90 & 0.9044 & 165 & 0.0618 \\
105 & 0.6302 & 180 & 0.0569 \\
120 & 0.3684 & 195 & 0.0284 \\
\hline
\end{tabular}

1975 - 2009 yılları arasında sağlanan yağış verileri, nem içerikleri, arazi kullanım/örtüsü ve hidrolojik toprak gruplarından SCS-CN yöntemi ile elde edilen akım verileri ile geçmiş yıllara ait hasar verileri dikkate alınarak yapılan Bilgi Difüzyonu analiz sonuçlarına göre; Ayamama Deresi $180 \mathrm{~m}^{3} / \mathrm{s}^{\prime}$ lik akıma ulaştığında taşkın olma olasılığının yaklaşık olarak \% 97.2 olacağı ve taşkın sularının yaklaşık 50 ha gibi bir alanda etkili olacağı belirlenmiştir.

\section{Tartışma}

Çalışmada, Ayamama Deresi’nde ilgili parametrelerin ağırlıklandırılması ile çok kriterli karar verme analizi yapılarak olası bir taşkın afetinde etkilenebilir alanlar belirlenmiş, akım miktarları seviyelendirilerek, taşkın riski için analiz edilmiş, buna göre Ayamama Deresi’nin akım seviyesi belirli bir değere ulaştığında, o değere ulaşması için geçen sürenin hesaplanarak, bu değerde taşkın olma olasılı̆̆ı ve taşkın olduğunda tüm havzanın ne kadarlık bir alanını etkileyeceği Bilgi Difüzyon Yöntemi kullanılarak belirlenmiş ve Hidrolik Modelleme çalışması ile de olası bir taşkında hasar görebilecek yerlerin alansal dağılımının belirlenmesi ile hasar etkileri değerlendirilmiștir. Buna göre yapılan çalışmada elde edilen sonuçlar doğrultusunda uygulanan yöntemlerin bir karșılaștırması Tablo 6'da sunulmuştur.

Çok kriterli karar verme yönteminde kullanılan kriterlerin yeterli olmaması ve bu kriterler arasındaki sınırlamaların, Hidrolik Modelleme'ye göre daha az olmasından dolayı taşkın risk analizi çalı̧̧malarında kullanılan iki yöntemin sınır koşulları göz önünde bulundurulduğunda Hidrolik Modellemenin daha doğru sonuçlar ortaya koyduğu belirlenmiştir. Taşkın tahmini ve su yönetimi için yeterli veri ihtiyacının karşılanması için hidrometrik ve meteorolojik ağların geliştirilmesi gerekmektedir.

Uydu görüntüleri, meteoroloji radarları ve LIDAR görüntüleri kullanılarak hazırlıklı olma ve taşkın yönetimi geliştirilebilir. Modern afet yönetimi sistemi dâhilinde taşkın için kayıp ve zarar azaltma, hazırlıklı olma, tahmin ve erken uyarı, afetler ve etki analizi gibi afet öncesi korumaya yönelik çalışmalara öncelik verilmelidir.

Bilgi Difüzyon yönteminden elde edilen sonuçların Hidrolik Modelde değerlendirilmesinde, taşkına maruz kalacak alanlar arasında fark gözlemlenmesinin nedeni uygulanan Bilgi Difüzyon yöntemi için gerekli gerçek verilerin tedarik edilememesi ve girdi olarak temsili verilerin kullanılmasından kaynaklanmaktadır. Ayamama Deresi'nin hem 2009 yilı hem de daha önceki yıllarda meydana gelen taşkınlar için herhangi bir hasar verisi tutulmadığ için yöntemde girdi olarak kullanılan veriler sadece tahmini değerler olması ve bu sebeple sistemin ürettiği sonuçların da buna bağlı olarak gerçek sonuçlarla örtüşememesidir.

Şiddetli yağışların oluşumuna zemin hazırlayan atmosferik kararsızlık koşulları nedeniyle Akdeniz iklim kuşağında yer alan ülkemizde meteorolojik kaynaklı doğal afetlerin kıyı kesimler başta olmak üzere özellikle ilkbahar ve sonbahar aylarında gerçekleşme ihtimali yıl boyunca mevcuttur. Deniz ve kara yüzeyleri arasındaki farklı ısınmanın ve orografinin getirdiği yağış oluşumunu desteklemekte, tropik ve polar hava kütleleri ve jet eksenleri Türkiye'nin bulunduğu enlemler üzerinde daha fazla birbirine yaklaşarak meteorolojik olayların şiddetini arttırmaktadır (Kömüşçü vd. 2011).

İstanbul gibi büyük şehirler için başta iklimsel ve fizyografik koşullar olmak üzere; ileriye yönelik yapılan klimatolojik tahminler, arazi kullanımı, plansız yapılaşmalar ile altyapı ve sosyo-ekonomik faktörleri de ele alarak taşkın afetini analiz etmek gerekmektedir (Öztürk vd. 2014; Türkeș 2016). Bu verilerin 1șığında; çalışmada yapılan uygulamaların daha güvenilir ve doğru sonuçlar üretebilmesi için geçmiş yıllara ait hidrolik modelleme veya farklı yöntemlerle belirlenmiş hasar etki alan verilerine de ihtiyaç duyulmaktadır. Ayrıca, taşkın tehlikesini yüksek doğrulukta belirleyebilmek için havzalardaki parametreler dikkatle izlenmelidir. Bu parametrelerin izlenmesi ile uygulanacak yöntemler taşkın tehlikesi öncesi önlem almayı sağlayacaktır. 
Tablo 6: Yöntemlerin karşılaştırması

\begin{tabular}{|c|c|c|c|c|}
\hline Yöntem & Avantaj & Dezavantaj & Kullanılabilirlik & Kullanılan Parametreler \\
\hline 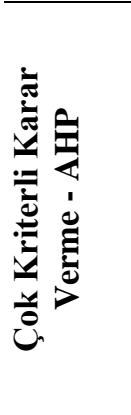 & $\begin{array}{l}\text { - Daha çok fiziki } \\
\text { coğrafya } \\
\text { parametreleri ile } \\
\text { çalışıldığı için } \\
\text { yöntemi } \\
\text { benimsemek } \\
\text { kolaydır. } \\
\text { - Her şey karar } \\
\text { vericinin } \\
\text { kontrolündedir. }\end{array}$ & $\begin{array}{l}\text { - Kullanılan kriterler } \\
\text { yeterli olmadığı zaman } \\
\text { doğru sonuç } \\
\text { üretilemiyor. } \\
\text { - Parameterelere verilen } \\
\text { ağırlıklar gerçeğe yakıı } \\
\text { sonuç çıkarmada önemli } \\
\text { rol oynuyor. Yani kişinin } \\
\text { kullandığı katsayılara } \\
\text { bağımlı bir yöntem. }\end{array}$ & $\begin{array}{l}\text { - Kullanım kolaylığı ve } \\
\text { formülasyon basit } \\
\text { olduğundan dolayı en sık } \\
\text { kullanılan yöntemdir. } \\
\text { - Karar vericinin ağırlık } \\
\text { değerlerini kendisinin } \\
\text { belirlemesinden ötürü karar } \\
\text { vericiye bağımlı bir } \\
\text { yöntemdir. }\end{array}$ & $\begin{array}{l}\text { - Havzanın sayısal yüzey } \\
\text { modeli } \\
\text { • Eğim } \\
\text { • Bakı } \\
\text { • Jeolojik özellikler } \\
\text { - Toprak ve arazi kullanımı }\end{array}$ \\
\hline 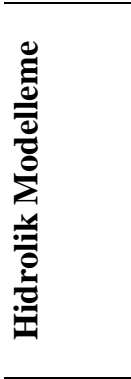 & $\begin{array}{l}\text { - Gelecekteki olası } \\
\text { taşkın olayları } \\
\text { modellenebilir. }\end{array}$ & $\begin{array}{l}\text { - Hidrolik frekans } \\
\text { analizlerinin iyi } \\
\text { yapılması gerekmektedir. } \\
\text { • Geçmişe ait akım } \\
\text { verilerine ihtiyaç var. }\end{array}$ & $\begin{array}{l}\text { - Geometrik verilerin temini } \\
\text { ile Manning katsayılarının } \\
\text { temini için uydu } \\
\text { görüntülerinin işlenmesi } \\
\text { gerekmektedir. } \\
\text { - Bünyesinde birçok } \\
\text { hesaplamayı } \\
\text { barındırmasından dolayı zor } \\
\text { bir yöntemdir. }\end{array}$ & $\begin{array}{l}\text { - Akış yönü } \\
\text { - Akış birikmesi } \\
\text { - Drenaj } \\
\text { - Havza geometrik akım } \\
\text { verileri } \\
\text { - Taşkın debisi } \\
\text { - Arazi kullanımı } \\
\text { - Akış yolları }\end{array}$ \\
\hline : & $\begin{array}{l}\text { - Taşkın hasar } \\
\text { index alanının } \\
\text { birebir } \\
\text { örneklenmesi } \\
\text { sonucu risk } \\
\text { değerlendirilmesi } \\
\text { etkin bir şekilde } \\
\text { yapılır. }\end{array}$ & $\begin{array}{l}\text { - Difüsyon fonksiyonunun } \\
\text { kalıbı ve difüzyon } \\
\text { katsayılarının } \\
\text { belirlenmesi } \\
\text { derinlemesine } \\
\text { araştırmayı gerektirir. }\end{array}$ & $\begin{array}{l}\text { - Formülasyonu basit olduğu } \\
\text { için kullanımı kolaydır. } \\
\text { • Çıkarılan sonuçların } \\
\text { irdelenmesi basittir. }\end{array}$ & $\begin{array}{l}\text { - Geçmiş yıllardaki havza } \\
\text { drenajları } \\
\text { - Yıllık maksimum ve } \\
\text { minimum taşkın seviyeleri } \\
\text { - Taşkın hasar index alanı } \\
\text { - Difüzyon katsayısı }\end{array}$ \\
\hline $\begin{array}{l}Z \\
\mathscr{U} \\
\mathscr{W}\end{array}$ & $\begin{array}{l}\text { - Küçük havzalarda } \\
\text { sağlıklı sonuçlar } \\
\text { vermektedir. }\end{array}$ & $\begin{array}{l}\text { • Günlük yağış kayıtlarına } \\
\text { ihtiyaç vardır. } \\
\text { • Yağış-akış farkını } \\
\text { dikkate almıyor. } \\
\text { • Bitki büyüme dönemi ile } \\
\text { kış dönemi sınırlarını } \\
\text { belirlemek oldukça zor. }\end{array}$ & $\begin{array}{l}\text { - Yöntemin uygulanması } \\
\text { arazide infiltrasyon testleri } \\
\text { yapılarak hidrolojik toprak } \\
\text { gruplarının belirlenmesi, } \\
\text { toprağın işlenme durumunun } \\
\text { belirlenmesi işlemlerine } \\
\text { dayandığı için zordur. }\end{array}$ & $\begin{array}{l}\text { - Yüzey akış miktarı } \\
\text { - Yağış miktarı } \\
\text { - Yüzey akış eğri numarası } \\
\text { • Sızma miktarı } \\
\text { - Başlangıçta tutulan yağış } \\
\text { miktarı } \\
\text { - Hidrolojik toprak sınıfları } \\
\text { - Arazi kullanımı }\end{array}$ \\
\hline
\end{tabular}

\section{Sonuç ve Öneriler}

Taşkın alanının belirlenmesi ve riskin ortaya çıkartılması için uygulanacak Çok Kriterli Karar Verme ve Hidrolojik Modelleme yöntemleri birbirlerine benzer sonuçlar ortaya koymaktadır. Ancak bu iki uygulamanın temel farklılıkları bulunmaktadır. Zira Çok Kriterli Karar Verme yöntemi uygulanırken fiziki coğrafya parametreleri temel alınmaktadır. Ancak Hidrolik Modelleme yapılırken daha çok akarsu yatak geometrisi özellikleri temel alınmaktadır. Hidrolik modellemenin en önemli avantajı gelecekteki olası taşkın olaylarının modellenebilmesini sağlamasıdır. Bu iki uygulamanın da güvenilir ve daha doğru sonuçlar verebilmesi için daha çok veriyle desteklenmesi gerekmektedir.

Difüzyon teorisi, risk değerlendirilmesi bakımından etkin bir metottur. Bu metot uygulanması bakımından diğer risk analizi yöntemlerine göre daha basit olup, sonuçları gözlemlemek daha kolay olmaktadır. Difüzyon teorisi, felaketlerin önlenmesinde rehberlik edebilir. Risk analiz yöntemiyle genetik analiz metodu birleştirildiğinde taşkın risk analizi daha iyi bir şekilde belirlenebilir ve sonunda taşkın kontrolünün başarımı ve felaketlerin daha makul seviyelere indirgenmesi sağlanabilir. Günümüze kadar yapılmış olan taşkın risk değerlendirmelerinin mükemmel bir sonuç vermediği göz önünde bulundurularak, taşkın felaketlerinin gözlenen serileri oldukça kısa olup bazen mevcut bulunamadığından dolayı difüzyon teorisi yönteminin de etkin ve pratik bir yöntem olarak kullanılabileceği düşünülmektedir. Ancak; difüzyon fonksiyonunun kalıbı ve difüzyon katsayılarının belirlenmesinde daha fazla derinlemesine araştırmaların yürütülmesi gerekmektir. Özellikle daha gerçekçi sonuçların ortaya çıkarılması için katsayıların doğru belirtilmesi ve formülün kalıbının uygun bir şekilde çıkarılması gerekmektedir. 
SCS-CN yönteminin küçük havzalarda sağlıklı sonuçlar verdiği saptanmış olmasına rağmen, uygulanmasında bazı sınırlamalar bulunmaktadır. Öncelikle, yöntemin uygulanması için havzayı temsil eden günlük yağış kayıtlarına gereksinim vardır. SCS-CN yöntemi yağışlardan kayıpları ve yüzeysel akışı modellediğinden, örneğin akifere akarsudan veya havza dışından beslenimin bu yöntemden yararlanılarak hesaplanması mümkün değildir. Yöntem ayrıca kar yağışı ve kar erimesini dikkate almamaktadır. Yöntemin en önemli varsayımı, yağış-akış arası zaman farkını dikkate almamasıdır. Bu nedenle yöntem küçük havzalarda uygulanmaktadır. Bitki büyüme dönemi ile kış dönemi sınırlarını belirlemek oldukça zordur. Bu sınır bölgeden bölgeye değiştiği gibi, bitki türüne göre ve hatta yıldan yıla değişmektedir. $\mathrm{Bu}$ nedenle, bu sınırı iyi belirlemek için o yörenin bitki türlerinin mevsimsel gelişimi ile iklimsel-meteorolojik koşullarının iyi bilinmesi gerekmektedir. Yöntemin uygulanması ile sağlıklı sonuçlar elde edilebilmesi için, toprak türü ile arazi örtüsü ve kullanımına en uygun $\mathrm{CN}$ değerinin belirlenmesi son derece önemlidir. Bunun için çalışılan arazinin çok iyi bilinmesinin yanı sıra, hava fotoğrafları ve uydu görüntüleri yardımıyla coğrafik bilgi sistemi uygulamalarından yararlanılması gerekmektedir.

Taşkın risk analizi çalışmalarında, havzanın fiziksel özellikleri ve bunlara bağlı parametrelerin kısa sürede güncellenmesi zordur. Uydu görüntüleri yardımıyla hem arazi kullanım bilgisi hem de meteorolojik veri güncellemeleri yapılarak güncel ve yüksek doğrulukta sonuçlar üretilebilmektedir.

Küresel iklim değişimi, plansız yerleşimler ve yetersiz altyapı nedeniyle taşkın afetleri can ve mal kaybına neden olmaktadır. Bunun için de akarsu havzaları içinde büyüyen yerleşimler, açılan yeni yollar ve kurulan yeni tesisler, elverişsiz tarım yöntemleri ile toprakların yoğun bir şekilde kullanılması, akarsu ve derelerin yatakları içinde veya mücavirindeki taşkın riski taşıyan alanların iskâna açılması, daha önce inşa edilmiş taşkın tesislerinin üzerlerinin kapatılması, açık mecraların kapalı mecralara dönüştürülmesi sonucunda büyük boyutlarda taşkın zararlarına neden olunması engellenmelidir. Taşkın yataklarındaki yerleşimler daha uygun yerlere taşınarak imar planları yenilenmelidir. Yerleşimin ve nüfus artışının yoğun olduğu bölgelerde yaşanan taşkın afetleri sonucunda büyük zararlar meydana gelmektedir. Bölgenin meteoroloji, hidroloji, topografya, morfoloji, bitki örtüsü vb. gibi faktörleri de hesaba alınarak, değişik sürelerde ortaya çıkabilecek yağış şiddetlerinden yararlanılarak gelecekteki taşkınlardan, taşkın yataklarında ortaya çıkabilecek yüzeysel su derinliklerinin önceden belirlenip bildirilmesi, izlenmesi ve gerekli uyarıların yapılabilmesi için meteorolojik tahmin ve erken uyarı sistemleri geliştirilmelidir. Uygulanan yöntemler, orta ve küçük ölçekte sel ve taşkın risk analizinin belirlenmesi amacıyla yapılan benzer çalışmaların; deprem, heyelan, çı̆̆ vb. afetler için de tasarlanması ve bu modeller kullanılarak ülke genelinde afet duyarlılık katmanlarının hazırlanması için bir altlık sağlayabilir.

\section{Kaynaklar}

Anlı A., (2006), Giresun Aksu havzası maksimum akımlarının frekans analizi, Akdeniz Üniversitesi Ziraat Fakültesi Dergisi, 19(1), 99-106.

Apaydın A., (2004a), Çakıloba-Karadoruk akifer sisteminin (Beypazarı Batısı-Ankara) beslenme koşullarının araştırılması, Doktora Tezi, Hacettepe Üniversitesi, Fen Bilimleri Enstitüsü.

Apaydın A., (2004b), SCS-CN yöntemi ve arazi kapasitesi değerleri kullanılarak yağıștan süzülme ve yeraltı suyu besleniminin tahmini, DSİ Jeoteknik Hizmetler ve Yeraltısuları Dairesi Başkanlığı, Yeraltısuları Semineri Ek Bildiriler Kitabı, DSİ, Ankara.

Bayazıt M., (1998), Hidrolojik modeller, İTÜ İnşaat Fakültesi Matbaası, İstanbul.

Bayazıt M., (2011), Hidroloji, Birsen Yayınevi, İstanbul, 219ss.

Boonstra J., (1994), Estimating peak runoff rates in: H. P. Ritzema (Ed.) drainage principles and applications, The NetherlandsInternational Institute for Land Reclamation and Improvement, 16, Wageningen, 111-144.

Chang Y., Chongfu H., Yaozhong P., (2007), Flood Disaster Risk Analysis for Songhua River Basin Based on Theory of Information Diffusion., ICCS 2007, Part III, LNCS 4489, 1069-1076.

Chow V.T., Maidment D.R., Mays L.W., (1988), Applied hydrology, McGraw Hill, Book Company, New York.

CEOS, (2003), The use of earth observing satellites for hazard support: assessments and scenarios, Final Report of the CEOS Disaster Management Support Group (DMSG), U.S. Department of Commerce, National Oceanic and Atmospheric Administration, 218ss.

Demir A., (2010), Şehir taşkınlart ve İstanbul, İSKİ Faaliyet Raporu, 2010.

Doorenbos J., Pruitt W.O., (1977), Guidelines for predicting crop water requirements, FAO-ONU, Rome, Irrigation and Drainage Paper no. 24 (rev.), 144 pp.

Einfalt T., Keskin, F., (2010), Analysis of the Istanbul Flood 2009, BALWOIS 2010 - Ohrid, Republic of Macedonia - 25, 29 May 2010.

Evren R., Ülengin F., (1992), Yönetimde çok amaçlı karar verme, İTÜ Yayınları, İstanbul.

Fleckkenstein J., (1998), Using GIS to derive velocity fields and travel times to route excess rainfall in a small scale watershed, Univ. of California Davis.

Görcelioğlu E., (2003), Sel ve çı̆̆ kontrolü, İ.Ü. Yayınları, İstanbul.

Hawkins Ré.H., (1998), Local Sources for Runof Curve Numbers, $11^{\text {th }}$ Proceedings of the Annual Symposium of the Arizona Hydrological Society, Tuscon, ss.23-26.

Hızal A., Şengönül K., Çelik H. E., Aşk K., Küçükkaya İ., (2009), İstanbul ilinde 8-9 Eylül 2009 tarihlerinde meydana gelen seller ve nedenleri hakkında değerlendirme raporu, Orman Mühendisleri Odası Yayın Kurulu, Eylül 2009.

Huang C.F., (1997), Principle of information diffusion, Fuzzy Sets and Systems, 91(1), 69-90.

Huang C.F., (2002), Information diffusion techniques and small-sample problem, International Journal of Information Technology \& Decision Making, 1(2), 229-49. 
Kadıŏlu M., (2008), Sel, heyelan ve çığ için risk yönetimi, Kadığlu, M. ve Özdamar, E., (editörler), “Afet Zararlarını Azaltmanın Temel İlkeleri”; s. 251-276, JICA Türkiye Ofisi Yayınları No: 2, Ankara.

Kilıçer Ü., Değirmencioğlu N., Yayvan M., (2000), Meteorolojik Kaynaklı Doğal Afetler Alt Komisyon Raporu, DPT Doğal Afetler Özel İhtisas Komisyonu Başkanlığı, Ankara, 28ss.

Kirmencioğlu B., (2015), Türkiye'de dere yataklarına müdahalelerin taşkınlar üzerindeki etkilerinin değerlendirilmesi, Uzmanlık Tezi, Orman ve Su İşleri Bakanlığı.

Kömüşü A.Ü., Çelik S., Ceylan A., (2011), 8-12 Eylül 2009 tarihlerinde Marmara Bölgesi’nde meydana gelen sel olayının yă̆ıs analizi, Coğrafi Bilimler Dergisi, 9(2), 209-220.

Lihua F., Gaoyuan, L., (2008), Flood risk analysis on information diffusion theory, Human and Ecological Risk Assessment, 14(6), $1330-1337$.

Linsley R.K., Kohler M.A., Paulhus J.L.H., (1989), Hydrology for engineers, McGraw-Hill, London, UK, 512ss.

Lolis C.J., Türkeş M., (2016), Atmospheric circulation characteristics favouring extreme precipitation in Turkey, Climate Research, 71(2), 139-153.

Melesse A.M., Graham W.D., Jordan J.D., (2003), Spatially distributed watershed mapping and modeling: GIS-based storm runoff response and hydrograph analysis: part 2, Journal of Spatial Hydrology, 3(2), 1-27.

Mossberger K., Hale K., (2002), Polydiffusion in intergovernmental programs: Information diffusion in the school-to-work network, American Review of Public Administration, 32(4), 398-422.

Nyarko B.K., (2002), Application of a rational model in GIS for flood risk assessment in Accra, Ghana, Journal of Spatial Hydrology, 2(1), 1-14.

Onuşluel G., Harmancıŏlu N.B., (2002), Su kaynaklı doğal afet: taşkın, TMH-Türkiye Mühendislik Haberleri, Sayı 420-421422/2002/4-5-6, 131-132.

Özcan O., (2007), Sakarya Nehri Alt Havzası'nın taşkın risk analizinin uzaktan algılama ve CBS ile belirlenmesi, Yüksek Lisans Tezi, Bilişim Enstitüsü, İstanbul.

Özcan O., Musaoglu N., Seker D.Z., Tanik A. (2008), Determination of flood risk in Sakarya sub basin using remotely sensed data and GIS, Fresenius Environmental Bulletin, 17(11b), 1964-1971.

Özcan O., Musaoğlu N., (2009), Taşkın Risk Analizinde Hidrolojik Modelleme ve Çok Kriterli Karar Verme Yöntemi, TUFUAB V. Teknik Sempozyumu, 4-6 Şubat, Ankara.

Özcan O., Saral A., Musaoğlu N., (2011), Hidrolojik Modellemenin Bilgi Difüzyon Teorisi Kullanılarak Uzaktan Algılama ve CBS ile Değerlendirilmesi, TUFUAB VI. Teknik Sempozyumu, 21-25 Şubat, Antalya.

Özdemir H., (1978), Uygulamalı taşkın hidrolojisi, DSİ Genel Müdürlüğü Basım ve Foto-Film İşletme Müdürlüğü Matbaası, Ankara.

Özdemir H., (2007), Havran Çayı havzasının CBS ve uzaktan algılama yöntemleriyle taşkın ve heyelan risk analizi, Doktora Tezi, İ.Ü. Sosyal Bilimler Enstitüsü, İstanbul.

Özer Z., (1990), Su yapılarının projelendirilmesinde hidrolojik esaslar, Köy Hizmetleri Genel Müdürlügü, Ankara.

Özer Z., (2008), Tarımsal altyapı hizmetlerinde drenaj ve arazi ıslahı mühendisliği, Tarım ve Köyişleri Bakanlığı Tarım Reformu Genel Müdürlüğü, Ankara.

Öztürk D., (2009), Risk analizi, CBS tabanlı çok ölçütlü karar analizi yöntemleri ile sel ve taşkın duyarlılığının belirlenmesi: Güney Marmara Havzası örneği, Doktora Tezi, Y.T.Ü. Fen Bilimleri Enstitüsü, İstanbul.

Öztürk T., Türkeş M., Kurnaz M.L., (2014), RegCM4.3.5 İklim modeli benzetimleri kullanılarak Türkiye'nin gelecek hava sıcaklı̆̆ ve yağış klimatolojilerindeki değişikliklerin çözümlenmesi, Ege Coğrafya Dergisi, 20(1), 17-27.

Palm R., (2007), Multiple-step-ahead prediction in control systems with Gaussian process models and TS-fuzzy models, Engineering Applications of Artificial Intelligence, 20(8),1023-35.

Saral A., (2010), Çok kriterli karar verme ve bilgi difüzyonu yöntemleri yardımıyla taşkın risk analizi yazılımının gerçekleştirilmesi, Yüksek Lisans Tezi, İTÜ, Bilişim Enstitüsü, İstanbul.

SCS, (1975), Urban hydrology for small watersheds, tech. Rel. No. 55, U. S. Dept. of Agriculture, Washington D.C.

Tatlı H., Türkeş M., (2011), Türkiye'nin Kurak ve Nemli Koşullarının Model Çıktı İstatistiği (MOS) ile İncelenmesi, $5^{\text {th }}$ Atmospheric Science Symposium, 27-29 April, İstanbul, ss.219-229.

Suzanne B., (2004), Managing toxic chemicals in Australia: A regional analysis of the risk society, Journal of Risk Research, 7(4), $399-412$.

Temuçin E., (1990), Aylık değişme oranlarına göre Türkiye'de yağış rejimi tipleri, Ege Coğrafya Dergisi, 5, 160-183.

Türkeş M., (1998), Influence of geopotential heights, cyclone frequency and southern oscillation on rainfall variations in Turkey, International Journal of Climatology,18(6), 649-680.

Türkeş M., (2010), Klimatoloji ve meteoroloji, Kriter Yayınevi, İstanbul, 650ss.

Türkeş M., (2012), Türkiye’de gözlenen ve öngörülen iklim değişikliği, kuraklık ve çölleşme, Ankara Üniversitesi Çevrebilimleri Dergisi, 4(2), 1-32.

Türkeş M., (2016), Genel klimatoloji: Atmosfer, hava ve iklimin temelleri, Kriter Yayınevi, İstanbul, 522ss.

Ulugür M.E., (1972), Su mühendisliği, Çağlayan Kitabevi, İstanbul.

URL-1, (2016), Yukarı havza sel kontrolü eylem planı (2013-2017), Orman ve Su İşleri Bakanlığı, Çölleşme ve Erozyonla Mücadele Genel Müdürlüğ̈̈, Ankara, https://www.ogm.gov.tr/ekutuphane/Yayinlar/Yukar\%C4\%B1\%20Havza\%20Sel\%20Kontrol\%C3 \%BC\%20Eylem\%20Plan\%C4\%B1.pdf, [Erişim 20 Aralık 2016].

URL-2, (2016), Il çevre durum raporu, İstanbul Çevre ve Şehircilik İl Müdürlüğü, Çevresel Etki Değerlendirmesi Şube Müdürlüğü, İstanbul, http://www.csb.gov.tr/db/ced/editordosya/Istanbul_icdr2013.pdf, [Erişim 20 Aralık 2016].

URL-3, (2010), Köprüler yaptırdım Askaroz Deresi'ne, http://www.beylikduzuhaber.gen.tr/Yazarlar-op-Oku-artid-7.html, [Erişim 25 Nisan 2010].

URL-4, (2010), http://www.ibb.gov.tr/trR/Pages/Haber.aspx?NewsID=17791, [Erişim 25 Nisan 2010].

Usta A., (2016), Türkiye’nin su potansiyelinin belirlenmesi üzerine bir araștırma, Küresel Mühendislik Çalışmaları Dergisi, 3(2), 1-9.

Yaralıŏlu K., (2004), Uygulamada karar destek yöntemleri, İlkem Ofset, İzmir, 2004.

Yoon K., Hwang C., (1995), Multiple attribute decision making: An introduction, Sage Publications, Thousand Oaks, CA, 83ss. 